\title{
ANÁlise florística do COMPaRTimento arbóreo de áreas de Floresta ATLÂNTICA SENSU lato Na REgiño das BaCIas do LeSte (Bahia, Minas Gerais, Espírito Santo e Rio de Janeiro)
}

Ary T. Oliveira-Filho ${ }^{1}$, Eugênio Tameirão-Neto, Warley A. C. Carvalho ${ }^{2}$, Márcio Werneck ${ }^{2}$, Ana Elisa Brina ${ }^{2}$, Cristiano V. Vidal, Saulo C. Rezende \& José Aldo Alves Pereira ${ }^{3}$

\begin{abstract}
Resumo
(Análise florística do compartimento arbóreo de áreas de floresta atlântica sensu lato na região das Bacias do Leste (Bahia, Minas Gerais, Espírito Santo e Rio de Janeiro)) As variações da composição da flora arbórea de 60 áreas de floresta atlântica sensu lato (ombrófilas e semidecíduas) da região das Bacias do Leste, englobando o sul da Bahia, o Espírito Santo, o leste de Minas Gerais e o norte do Rio de Janeiro, são analisadas em articulação com variáveis geográficas e climáticas. Listagens de espécies são fornecidas para 16 destas áreas. Análises multivariadas detectaram três padrões de distribuição. (a) A diferenciação entre florestas ombrófilas e semidecíduas na região é floristicamente consistente e fortemente correlacionada com a sazonalidade do regime de chuvas. A flora arbórea das florestas semidecíduas é, em boa medida, um subconjunto da flora das florestas ombrófilas, extraindo espécies provavelmente mais eficientes em resistir e competir sob condições de seca mais prolongada. (b) Existe uma diferenciação latitudinal tanto para florestas ombrófilas e semidecíduas, que aproxima floristicamente as duas fisionomias dentro da mesma faixa latitudinal. Este padrão é causado provavelmente por variações térmicas e pluviométricas. As florestas ombrófilas são interrompidas no norte fluminense devido ao clima estacional, mas isto não tem como contrapartida uma disjunção na distribuição de espécies arbóreas. (c) As variações da altitude estão fortemente correlacionadas com a diferenciação interna tanto das florestas ombrófilas como das semidecíduas.
\end{abstract}

Palavras-chave: fitogeografia, flora arbórea, Brasil Oriental, Mata Atlântica.

\section{Abstract}

(Floristic analysis of the tree component of atlantic forest areas in Central Eastern Brazil) Variations in tree species composition of 60 areas of atlantic forest sensu lato (rain- and semideciduous forests) of CentralEastern Brazil are analyzed in combination with geographic and climatic variables. Floristic checklists are provided for 16 areas. Multivariate analyses detected three main distribution patterns. (a) Differentiation between rain- and semideciduous forests in the region is floristically consistent and strongly correlated with rainfall seasonality. To a considerable extent, the tree flora of semideciduous forests is a subset of that of rainforests, extracting species that are more efficient in coping with a longer dry season. (b) There is a latitudinal differentiation for both rain- and semideciduous forests, that draws the two physiognomies together floristically present within the same latitudinal range. This pattern is probably caused by variations of both temperature and rainfall. The rainforests are interrupted in northern Rio de Janeiro state, due to the seasonal climate, but this has no counterpart in disrupted species distribution. (c) Variations in altitude are strongly correlated to internal variations of both rain- and semideciduous forests.

Key-words: phytogeography, tree flora, Eastern Brazil, Atlantic Forest.

\section{INTRODUÇÃO}

Devido à sua significativa contribuição para a diversidade biológica planetária e ao seu elevado nível de degradação, o bioma floresta atlântica foi eleito um dos 25 hotspots de biodiversidade do mundo (Myers et al.
2000) e tem sido alvo de uma série de iniciativas que buscam orientar a conservação de seus remanescentes, os quais correspondem hoje a menos de $8 \%$ da cobertura original (MMA 2002; Galindo-Leal \& Câmara 2003). Como a falta de informação é um dos

Artigo recebido em 01/2005. Aceito para publicação em 06/2005.

${ }^{1}$ Professor Titular, Depto. Ciências Florestais, Universidade Federal de Lavras, 37200-000, Lavras, MG. ary@ vialavras.com.br.

${ }^{2}$ Doutorandos. Depto. Botânica, Universidade Federal de Minas Gerais. Av. Antônio Carlos s/n, 31270-901, Belo Horizonte, MG.

${ }^{3}$ Professor Titular, Depto. Ciências Florestais, Universidade Federal de Lavras, 37200-000, Lavras, MG. 
principais obstáculos a estas iniciativas, uma das principais linhas de ação tem sido investigar e caracterizar os padrões de distribuição geográfica e ecológica de grupos de espécies que integram esta biodiversidade (Carneiro \& Valeriano 2003; Silva \& Casteleti 2003).

Um dos principais grupos de organismos da floresta atlântica cuja distribuição ecogeográfica tem sido crescentemente investigada é o das árvores. Isto se deve, em parte, ao fato de elas serem o componente que mais contribui para a biomassa viva da floresta atlântica e também à disponibilidade de inventários da comunidade arbórea, que vem crescendo rapidamente em toda a extensão geográfica do bioma (Scudeller \& Martins 2003). Historicamente, os primeiros estudos do gênero foram feitos para a floresta atlântica de São Paulo porque este estado foi um dos primeiros a acumular uma massa de informações suficiente para as análises (Salis et al. 1995; Torres et al. 1997; Scudeller et al. 2001). Seguiram-se trabalhos na mesma linha para outros estados, como Minas Gerais (Oliveira-Filho et al. 1994) e Rio de Janeiro (Peixoto et al. 2004) e regiões inteiras, como a Sudeste (Oliveira-Filho \& Fontes 2000) e Nordeste (Ferraz et al. 2004). De amplitude geográfica ainda maior, há o trabalho pioneiro de Siqueira (1994), com a análise de 63 áreas de floresta atlântica sensu stricto (florestas ombrófilas apenas) das Regiões Nordeste, Sudeste e Sul.

Em sua análise da composição florística do compartimento arbóreo de 125 áreas de floresta atlântica sensu lato (ombrófilas e estacionais) distribuídas entre o estado do Paraná e o sul da Bahia, Oliveira-Filho \& Fontes (2000) identificaram uma série de padrões de distribuição associados a variáveis geográficas e climáticas. No entanto, os autores perceberam que, em contraste com outros setores geográficos, como o sul da Bahia e os estados de São Paulo e Rio de Janeiro, havia uma relativa escassez de levantamentos na região das Bacias do Leste, particularmente no leste de Minas Gerais e sul do Espírito Santo. O presente trabalho procura preencher esta lacuna com a análise da flora arbórea de 60 áreas de floresta atlântica sensu lato desta região. Deste total, 23 áreas são novas em relação àquelas analisadas por Oliveira-Filho \& Fontes (2000) e as listagens de espécies de 16 delas são aqui apresentadas. Três padrões descritos pelos autores para o Sudeste do Brasil foram investigados no contexto geográfico mais restrito da região das Bacias do Leste.

O primeiro padrão florístico trata da distinção entre florestas ombrófilas e semidecíduas, que Oliveira-Filho \& Fontes (2000) afirmaram ser consistente e vinculada principalmente à sazonalidade da precipitação. No entanto, esta distinção não teria um caráter de substituição abrupta, mas de um contínuo onde predomina a supressão gradativa de espécies mais vinculadas ao clima pluvial na medida em que aumenta a duração da estação seca. Segundo os autores, esta transição seria mais curta ao sul, onde as montanhas costeiras contribuem para um gradiente climático mais brusco, e mais gradual onde o relevo é mais discreto, como nas bacias dos rios Doce, Mucuri e Jequitinhonha. No presente trabalho, a repetição deste padrão é investigada para região das Bacias do Leste, a qual inclui essas três bacias.

O segundo padrão é a variação latitudinal apresentada pela flora tanto das florestas ombrófilas como das semidecíduas, de forma a aproximar floristicamente as florestas ombrófilas das semidecíduas vizinhas tanto ao norte como ao sul da região estudada. As variações térmicas latitudinais seriam importantes para este padrão, mas o regime de chuvas também varia com a latitude na região. No caso das florestas ombrófilas, Oliveira-Filho \& Fontes (2000) sugeriram que o padrão florístico estaria fortemente relacionado com a variação dos índices pluviométricos na faixa costeira, que apresentam dois máximos, um na Bahia e outro 
em São Paulo, e uma redução gradual na direção do norte fluminense. Nessa região, a distribuição das florestas ombrófilas é interrompida e as florestas semidecíduas chegam até o oceano. Conhecida como 'Falha de Campos dos Goytacazes', a região é considerada um limite natural entre duas divisões biogeográficas da floresta atlântica costeira: o Corredor da Serra do Mar, entre o Rio de Janeiro e o Paraná, e o Corredor do Descobrimento, ou Central, no Espírito Santo e Bahia (Aguiar et al. 2003; CABS 2000). O presente trabalho examina a diferenciação florística norte-sul na região das Bacias do Leste e verifica se esta corresponde a alguma descontinuidade na distribuição de espécies arbóreas na altura da Falha de Campos dos Goytacazes.

O terceiro padrão florístico investigado na região das Bacias do Leste trata das variações altitudinais tanto das florestas ombrófilas como semidecíduas. Este tem sido um dos padrões identificados com maior clareza em florestas atlânticas de diversas regiões, como o estados de São Paulo (Salis et al. 1995; Torres et al. 1997; Scudeller et al. 2001) e Rio de Janeiro (Peixoto et al. 2004), o sul de Minas Gerais (Oliveira-Filho et al. 1994) e a Região Nordeste (Ferraz et al. 2004).

\section{Material e Métodos}

\section{Levantamentos florísticos e das variáveis geográficas e climáticas}

Listagens da flora arbórea foram compiladas para 16 áreas de floresta atlântica sensu lato da região das Bacias do Leste, sendo uma delas (Castelo) situada na bacia do rio Itapemirim, sul do Espírito Santo, e as outras 15 no leste de Minas Gerais, nas bacias dos rios Paraíba do Sul (Miraí e Carangola), Doce (Mariana, Rio Doce, Santa Bárbara, Itambé do Mato Dentro, Braúnas/ Joanésia, São Pedro do Suaçuí, Governador Valadares e Aimorés), Jequitinhonha (Chapada de São Domingos, Leme do Prado,
Posses e Virgem da Lapa) e Itanhaém (Machacalis). A situação geográfica destas áreas é indicada na Figura 1.

As listagens de espécies arbóreas resultaram de levantamentos fitossociológicos e florísticos conduzidos nas 16 áreas. Os levantamentos fitossociológicos de Machacalis e Itambé do Mato Dentro foram realizados em, respectivamente, 25 parcelas de $20 \times 20$ $\mathrm{m}$ e 35 de $15 \times 15 \mathrm{~m}$. Nas outras 14 áreas foi utilizado o método dos quadrantes, sendo distribuídos 500 pontos, cada um com quatro quadrantes (2.000 árvores) em cada uma delas. Em todos levantamentos, foram registrados apenas indivíduos de hábito arbóreo (lianas excluídas) e o diâmetro mínimo

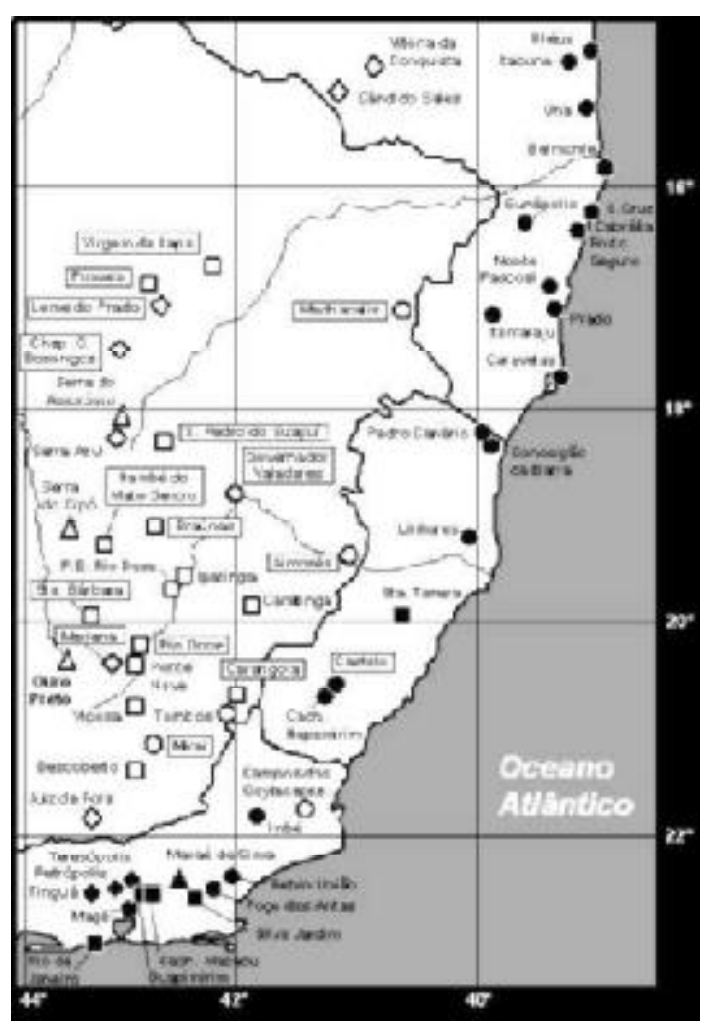

Figura 1- Localização das 60 áreas de Mata Atlântica sensu lato utilizadas nas análises florísticas. Os nomes das 16 áreas que compõem o presente estudo são salientados em caixas. As florestas são classificadas em ombrófilas ou semidecíduas (símbolos fechados ou abertos, respectivamente) e em quatro pisos altitudinais: das terras baixas (ò ô ) submontanas $(\Varangle \mathfrak{f})$, baixomontanas $(\varnothing \varnothing)$ e alto-montanas $(p r)$. 
de inclusão foi de $5 \mathrm{~cm}$ de DAP (diâmetro à altura do peito ou 1,3 m do solo). Os resultados dos estudos fitossociológicos sãoainda inéditos, exceto os de Itambé do Mato Dentro (Carvalho et al. 2000; Oliveira-Filho et al. 2004). Os levantamentos florísticos das espécies arbóreas foram feitos a partir do material testemunho coletado nas unidades amostrais (parcelas ou quadrantes), acrescido de coletas realizadas em caminhamentos pelas áreas. O material botânico testemunho foi herborizado e depositado no herbário da Universidade Federal de Lavras (Herbário ESAL). As identificações foram feitas com auxílio de literatura especializada e consultas a especialistas e às coleções dos Herbários ESAL, BHCB (Universidade Federal de Minas Gerais), SP (Instituto de Botânica de São Paulo), RB(Instituto de Pesquisas Jardim Botânico do Rio de Janeiro) e UEC (Universidade Estadual de Campinas). Para duas áreas, as listagens de espécies foram complementadas por registros de levantamentos conduzidos por outros autores: Santa Bárbara (CETEC 1989; Pedralli \& Teixeira 1997) e Carangola (Leoni 1991). As espécies foram classificadas nas famílias reconhecidas pelo sistema do Angiosperm Phylogeny Group II (APG 2003).

Para enriquecimento das análises florísticas, foram extraídas da literatura listagens da flora arbórea de 44 áreas de floresta atlântica sensu lato da mesma região, totalizando 60 áreas. De acordo com os critérios de Oliveira-Filho \& Fontes (2000), estas 60 áreas foram classificadas como florestas ombrófilas ou semidecíduas e divididas em quatro classes altitudinais, resultando em oito categorias de formações florestais. As áreas de floresta ombrófila das terras baixas foram, no estado da Bahia, Una (Harley \& Mayo 1980; Mori et al. 1983; Tavares et al. 1979; Thomas et al. 2004; Veloso 1946a, 1946b); Ilhéus e Itabuna (Harley \& Mayo 1980; Thomas \& Carvalho 2004a; Veloso 1946a, 1946b); Belmonte, Santa Cruz
Cabrália, Itamaraju e Prado (Harley \& Mayo 1980; Tavares et al., 1979); Eunápolis (Elias Jr. 1998); Porto Seguro (Harley \& Mayo 1980; Paraguassu, 1999; Tavares et al. 1979); Monte Pascoal (Harley \& Mayo 1980; Soares \& Ascoly 1970; Thomas \& Carvalho 2004b) e Caravelas (Souza et al. 1998); no estado do Espírito Santo, foram Pedro Canário (Souza 1998), Conceição da Barra (Salomão 1998), Linhares (Heinsdijk et al. 1965; Jesus \& Garcia, 1992; Peixoto \& Gentry 1990) e Cachoeiro de Itapemirim (Costa et al. 2004); e, no estado do Rio de Janeiro, foram ReBio União (Rodrigues 2004), Poço das Antas (Guedes-Bruni 1998; IBDF 1981; Neves 2001) e Magé (Guedes 1989). As áreas de floresta ombrófila submontana foram, no estado do Espírito Santo, Santa Tereza (Thomaz \& Monteiro 1997) e, no estado do Rio de Janeiro, Imbé (Amorim 1984; Moreno et al. 2003), Guapimirim (Guedes-Bruni 1998), Cachoeira de Macacu (Kurtz \& Araujo 2000), Silva Jardim (Borém \& Oliveira-Filho 2002; Borém \& Ramos 2001) e Rio de Janeiro (Santos 1976). As três áreas de floresta ombrófila baixo-montana, todas no Rio de Janeiro, foram Teresópolis (Amorim 1984; Veloso 1945), Petrópolis (FNMA \& Instituto ECOTEMA 2001) e Tinguá (Braz et al. 2004; Rodrigues 1996). Também no Rio de Janeiro, aúnica área de floresta ombrófila alto-montana foi Macaé de Cima (Guedes-Bruni 1998; Lima \& Guedes-Bruni 1994).

As áreas de floresta semidecídua das terras baixas foram, Tombos (Cosenza 2003), em Minas Gerais, e Campos dos Goitacazes (Silva \& Nascimento 2001), no Rio de Janeiro. As áreas de floresta semidecídua baixomontana, todas em Minas Gerais, foram Ipatinga (Paula et al. 2000), Parque Estadual do Rio Doce (CETEC 1982; Lombardi \& Gonçalves 2000; Lopes et al., 2002), Caratinga (Lombardi \& Gonçalves 2000), Ponte Nova/Guaraciaba (Meira-Neto et al. 1997a, 1997b, 1997c, 1998), Viçosa (Marangon et al. 2003; Meira-Neto \& Martins 2000a, 
2000b, 2002; Meira-Neto et al. 2003; Paula et al. 2004; Silva et al., 2000, 2003; Sevilha et al. 2001; Ribas et al. 2003) e Descoberto (Forzza et al., dados não publicados). As áreas de floresta semidecídua baixo-montana foram, no estado da Bahia, Vitória da Conquista e Cândido Sales (Soares-Filho 2000) e, no estado de Minas Gerais, Serra Azul/Rio Vermelho (Ferreira 1997) e Juiz de Fora (Almeida \& Souza 1997; Pifano 2004). As áreas de floresta semidecídua alto-montanas, todas em Minas Gerais, foram Serra do Ambrósio (Pirani et al. 1994), Serra do Cipó (Campos, 1995; Meguro et al. 1996a, 1996b), Ouro Preto (Pedralli et al. 1997; Werneck et al. 2000) e Araponga (Ribeiro 2003).

A situação geográfica e classificação das 60 áreas de floresta são indicadas na Figura 1 e variáveis geográficas e climáticas sobre as mesmas são fornecidas na Tabela 1. Médias anuais e mensais de temperatura e precipitação foram obtidas do DNMet (1992) ou da Rede Nacional de Agrometeorologia (2004). Para algumas áreas as médias foram geradas a partir de interpolação entre registros de áreas vizinhas e, ou, aplicação de correção para altitude, seguindo procedimentos descritos por Thornthwaite (1948).

\section{Análises florísticas}

Para realização das análises florísticas, foram preparados dois bancos de dados contendo informações florísticas e ambientais sobre as 60 áreas de floresta. $\mathrm{O}$ banco de dados florísticos consistiu de dados binários da presença de 2.350 espécies de árvores nas 60 áreas de floresta. $\mathrm{O}$ banco de dados ambientais consistiu das variáveis geográficas (a) latitude, (b) longitude, (c) altitude e (d) distância até o oceano e das variáveis climáticas (e) temperatura média anual, (f) temperatura média mensal de julho e $(\mathrm{g})$ temperatura média mensal de janeiro, (h) diferença térmica entre as médias de julho e janeiro, (i) precipitação média anual, (j) precipitação média mensal da estação seca (junho-agosto) e (l) precipitação média mensal da estação chuvosa (dezembrofevereiro), (m) 'distribuição da precipitação', obtida da razão entre as duas médias mensais anteriores e (n) 'duração média da estação seca', expressa pelo número de dias de déficit hídrico extraído de um diagrama de Walter (Walter 1985).

A análise de correspondência canônica, ou CCA (ter Braak 1987), processada pelo programa PC-ORD 4.0 (McCune \& Mefford 1999), foi a técnica de análise multivariada escolhida para investigar as relações entre a composição da flora arbórea nas 60 áreas de floresta e as variáveis geográficas e climáticas (daqui em diante, geoclimáticas). A CCA procura extrair padrões inter-relacionados de estrutura dos dados contidos em duas matrizes. Uma matriz florística com a ocorrência de 1.692 espécies foi extraída do banco de dados florísticos após exclusão das espécies ocorrentes em apenas uma das 60 áreas. Uma matriz de variáveis geoclimáticas foi extraída diretamente do banco de dados ambientais, contendo, inicialmente, todas as 13 variáveis. Após análises preliminares, foram eliminadas seis variáveis geoclimáticas com correlações mais fracas com os dois primeiros eixos de ordenação $(r<0,7)$ e alta redundância com pelo menos uma das sete variáveis mantidas na CCA final. As variáveis eliminadas foram a distância até o oceano (redundante com a duração da estação seca), as temperaturas médias mensais em janeiro e julho (redundantes com a altitude e temperatura média anual), a diferença térmica entre janeiro e julho (redundante com a latitude) e as precipitações médias mensais nas estações seca e chuvosa (redundantes com a duração da estação seca). O teste de permutação de Monte Carlo foi aplicado à CCA final para avaliar a significância das correlações encontradas. 


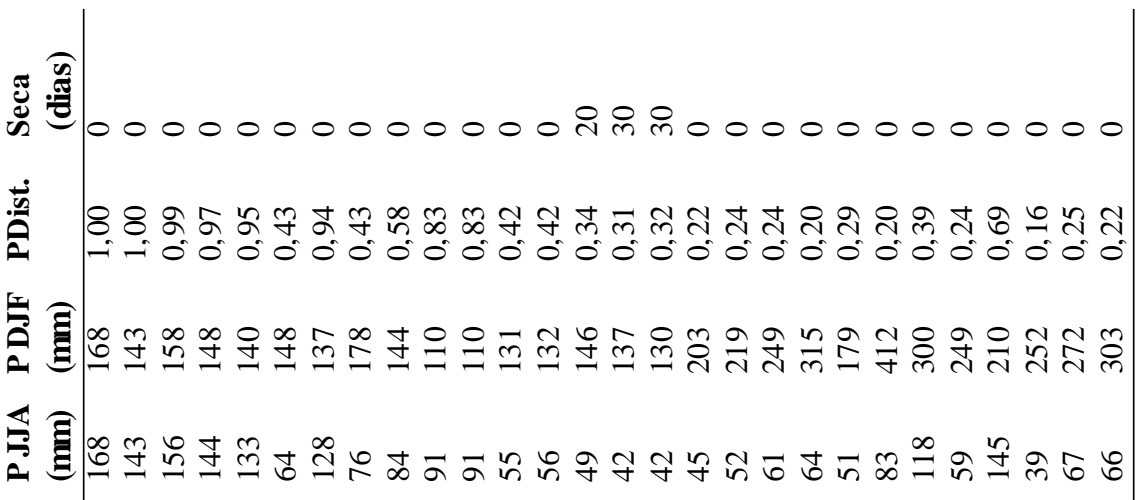

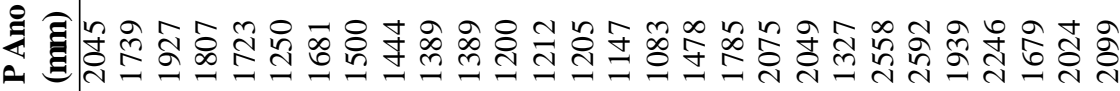

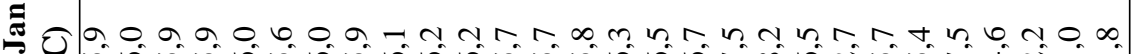

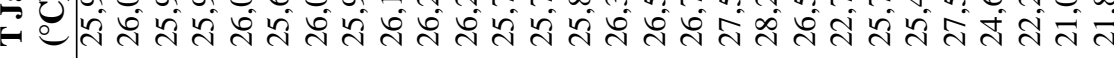

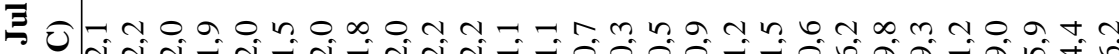

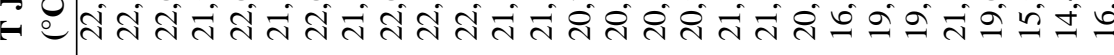
$\stackrel{3}{\circ}$

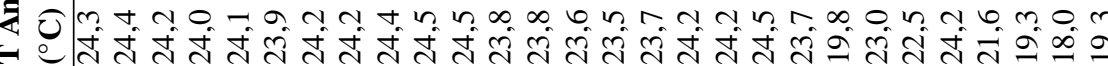
○்

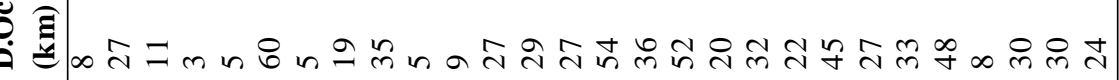
:

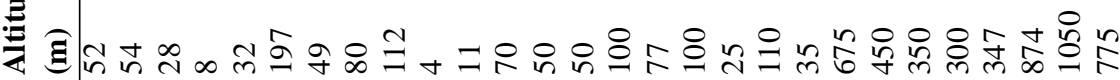
密合

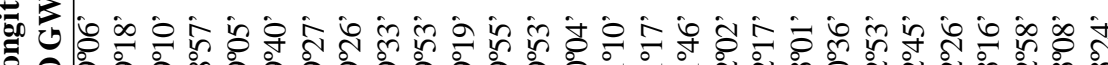

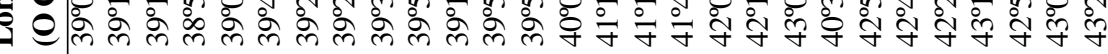
幽

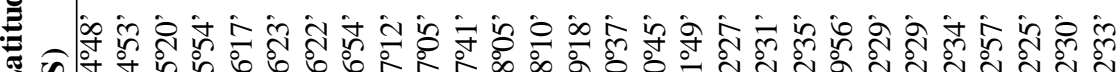

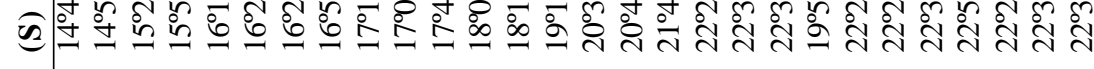
宽

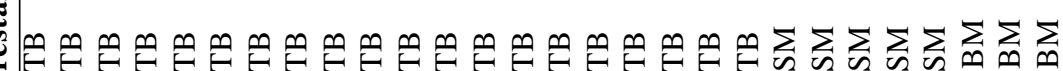

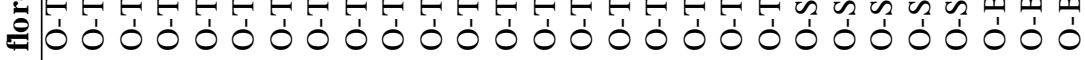
胥

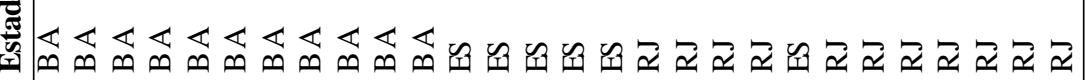

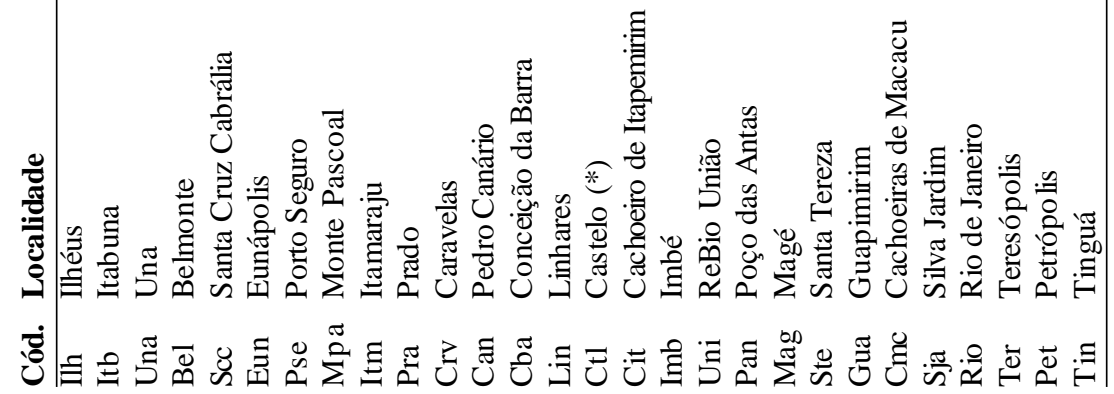




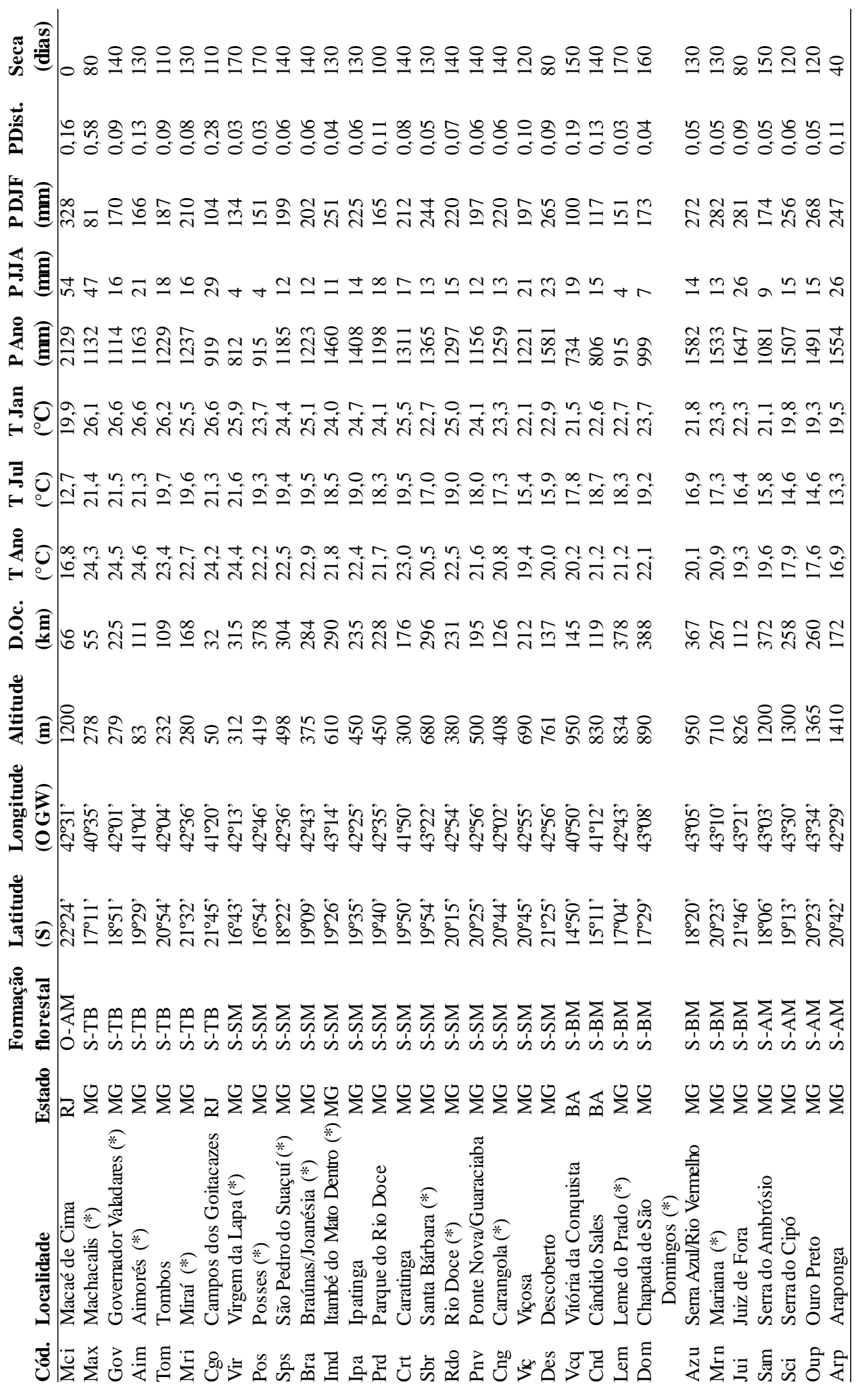




\section{Resultados e Discussão}

\section{Listagens de espécies}

A listagem das 1.021 espécies arbóreas registradas nas 16 áreas de floresta do presente estudo é fornecida na Tabela 2. Todas estão identificadas até espécie, pois foram excluídas aquelas identificadas somente até gênero ou família, as quais não ultrapassaram cinco morfo-espécies por área. Deste total, 906 espécies $(88,7 \%)$ também foram registradas em pelo menos uma das outras 44 áreas utilizadas nas análises, o que representa um incremento de apenas 115 espécies $(8,8 \%)$ aos trabalhos consultados (1.303 espécies). Se consideradas apenas as florestas semidecíduas, a contribuição foi bem maior, pois as 15 áreas do presente estudo (todas menos Castelo, ES) contabilizaram 954 espécies, as quais acrescentaram 228 espécies $(20,0 \%)$ às outras 17 áreas (1.147 espécies). A área de Castelo acrescentou somente três espécies ao conunto das demais áreas de floresta ombrófila.

A listagem completa das 60 áreas conteve 2.324 espécies, das quais 1.849 foram registradas nas 28 áreas de floresta ombrófila e 1.375 nas 32 áreas de floresta semidecídua. Estes números implicam em 900 espécies em comum, 949 espécies exclusivas das áreas de florestas ombrófilas e 475 espécies exclusivas das áreas de florestas semidecíduas. Em termos proporcionais, estes números correspondem, respectivamente, a 38,7\%, $40,8 \%$ e $20,4 \%$ do total de espécies, valores surpreendentemente semelhantes àqueles registrados por Oliveira-Filho \& Fontes (2000) em uma comparação entre áreas de floresta ombrófila e semidecídua de toda a Região Sudeste: respectivamente $40,0 \%, 39,5 \%$ e $20,5 \%$. Conforme afirmaram esses autores, estes números demonstram que a flora arbórea das florestas ombrófilas é consideravelmente mais rica e tem maior exclusividade de espécies que a das florestas semidecíduas, padrão este também registrado para as florestas do estado de São Paulo, por
Torres et al. (1997), e do Nordeste do Brasil, por Ferraz et al. (2004). Na verdade, a distribuição das florestas atlânticas ombrófilas é limitada por condições ambientais extremas de interferências oceânicas, temperaturas mais baixas, inundações ou estações secas mais prolongadas, onde é substituída por outras formações vegetais (Scarano 2002). Onde a seca se torna mais prolongada, as florestas semidecíduas sucedem as ombrófilas e boa parte da flora arbórea é composta simplesmente da fração da flora das próprias florestas ombrófilas que é capaz de resistir e competir com maior sucesso sob esta modalidade de estresse (Oliveira-Filho \& Fontes 2000).

\section{Análise florística}

A CCA produziu autovalores intermediários, respectivamente 0,423 e 0,314 para os eixos de ordenação 1 e 2 , indicando a existência de gradientes moderados, ou seja, parte das espécies distribui-se por todo o gradiente, mas parte delas é exclusiva de segmentos particulares (ter Braak 1995). Os dois primeiros eixos explicaram apenas $6,8 \%$ e $5,0 \%$ da variância global (total acumulado de $11,8 \%$ ), indicando muita variância remanescente não explicada (ruído elevado na estrutura dos dados). No entanto, tal situação é comum em dados de vegetação e não prejudica a significância das relações espécie-ambiente (ter Braak 1988). Com efeito, a CCA produziu valores muito altos para as correlações espécie-ambiente nos dois primeiros eixos $(r=0,989$ e $r=0,978)$. Além disso, os testes de permutação de Monte Carlo indicaram gradientes significativos (testes para autovalores, $p=0,01$, para ambos os eixos) e correlações significativas entre a distribuição das espécies e as variáveis ambientais fornecidas (testes para correlações espécie-ambiente, $p=0,01$, para ambos os eixos). As variáveis ambientais com correlações internas (intra-set) mais fortes ( $r$ $>0,7$ ) com o primeiro eixo foram, em ordem 


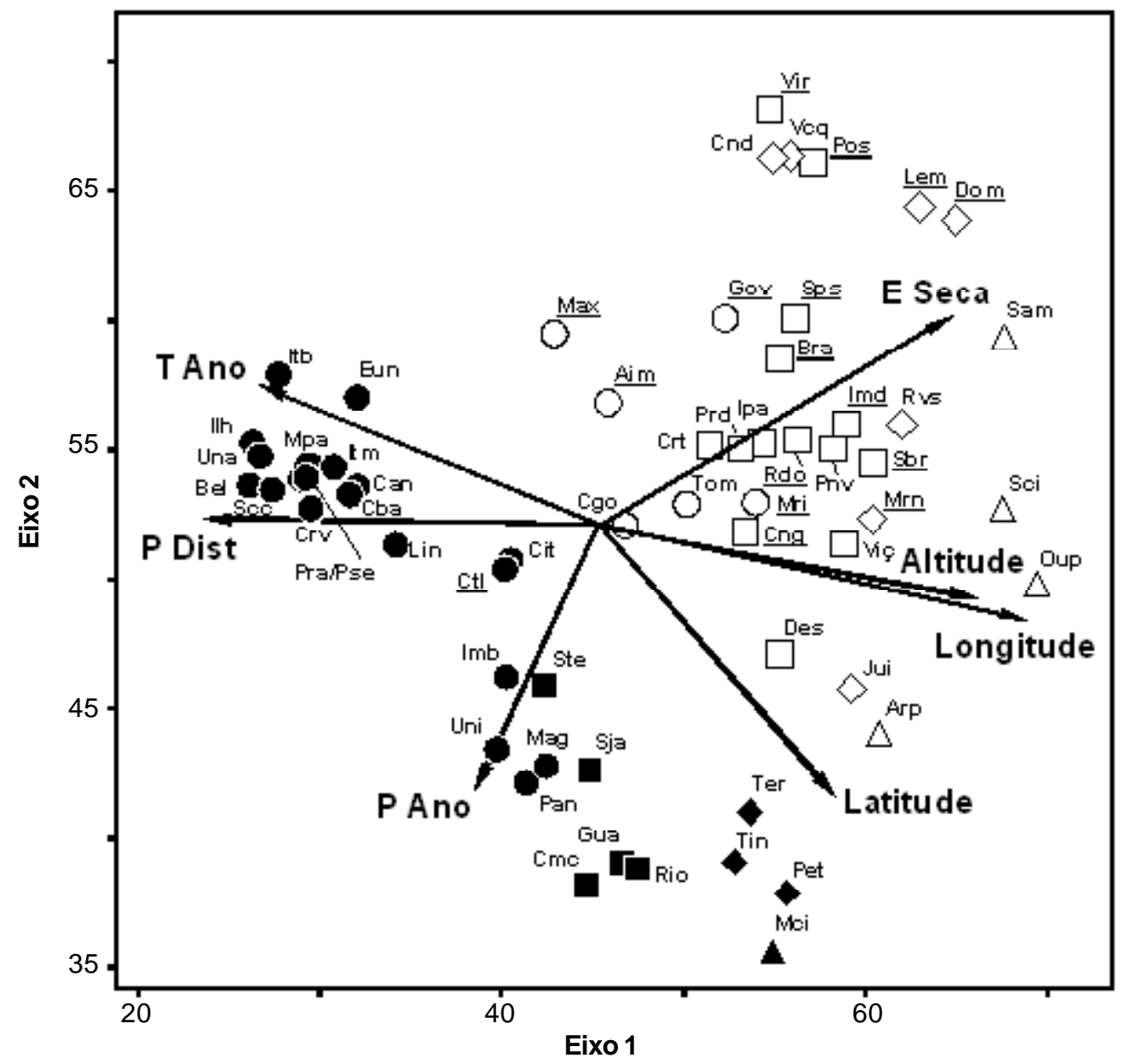

Figura 2 - Diagrama gerado pela análise de correspondência canônica (CCA) da presença de 1692 espécies arbóreas em 60 áreas de Mata Atlântica e sua correlação com variáveis geoclimáticas (setas). As áreas de Mata Atlântica são identificadas por seus códigos na Tabela 1 e classificadas em ombrófilas ou semidecíduas (respectivamente, símbolos fechados ou abertos) e em quatro pisos altitudinais: das terras baixas (ò ô ) submontanas $(\varnothing €$ ), baixo-montanas $(\varnothing \varnothing)$ e alto-montanas $(\mathrm{p} \mathrm{r}$ ). Os códigos das 16 áreas que compõem o presente estudo encontram-se sublinhados. T Ano = temperatura média anual; P Ano = precipitação média anual; P Dist = distribuição da precipitação; E Seca = duração da estação seca.

decrescente, longitude $(r=-0,925)$, distribuição da precipitação $(r=0,858)$, altitude $(r=-0,821)$, duração da estação seca $(r=-0,770)$ e temperatura média anual $(r=0,727)$. Para o segundo eixo, as variáveis mais fortemente correlacionadas foram latitude $(r=-0,746)$ e precipitação média anual $(r=-0,728)$.

A distinção entre florestas ombrófilas e semidecíduas ficou evidente no diagrama de ordenação gerado pela CCA, assim como sua forte vinculação com a duração da estação seca e, secundariamente, com a precipitação média anual (Figura 2). Contudo, tal separação não caracterizou dois grupos polarizados, mas adjacentes no sentido norte-sul, isto é, as florestas ombrófilas do norte estão mais próximas de suas vizinhas semidecíduas do norte do que das florestas ombrófilas do sul. Este padrão vem de encontro à afirmativa de Oliveira-Filho \& Ratter (1995) e de OliveiraFilho \& Fontes (2000) de que, ainda que haja uma distinção florística consistente entre florestas ombrófilas e semidecíduas do domínio Atlântico, estas duas fisionomias integram um mesmo contínuo com forte variação latitudinal. 
Como aqueles autores fizeram tal afirmativa dentro de contextos geograficamente mais amplos e com contrastes ambientais mais fortes, coube ao presente estudo demonstrar que o padrão se repete em um âmbito mais restrito, no caso o da região das Bacias do Leste.

Outro aspecto a ser analisado no que diz respeito às florestas ombrófilas é sua variação latitudinal, evidenciada principalmente pela CCA, em forte articulação com a temperatura média anual e distribuição da precipitação, ambos crescentes na direção norte. OliveiraFilho \& Fontes (2000) sugeriram que, na região das Bacias do Leste, haveria dois blocos florísticos relativamente distintos e separados pela Falha de Campos dos Goytacazes, no norte fluminense, onde o clima estacional alcança o oceano e interrompe a distribuição das florestas ombrófilas. Ao norte da Falha os índices pluviométricos tornam-se gradualmente maiores até alcançarem o máximo na região da Hiléia Sul-baiana. Ao sul os índices também se elevam até alcançar outro máximo no vale do Ribeira (SP). No entanto, uma análise mais apurada desta hipótese carecia de informações florísticas mais ricas sobre florestas ombrófilas capixabas ao sul do rio Doce, que foram incorporadas no presente estudo. Ao contrário do esperado por aqueles autores, a situação no diagrama da CCA das duas novas áreas desta região (Castelo e Cachoeiro de Itapemirim) sugere mais um gradiente contínuo das florestas ombrófilas do Rio de Janeiro até as do sul da Bahia do que uma interrupção florística, ainda que moderada, na altura do norte fluminense. Observe-se ainda que este contínuo observado para florestas ombrófilas de terras baixas é ainda reforçado pela situação da área de floresta ombrófila submontana de Santa Tereza (ES), cuja flora se assemelhou mais à das áreas de floresta ombrófila do Rio de Janeiro do que à das outras florestas capixabas.

O mesmo padrão norte-sul identificado para florestas ombrófilas pode ser observado do diagrama da CCA para as florestas semidecíduas, igualmente associado a temperaturas médias anuais crescentes na direção norte. No entanto, para ambas as tipologias, os padrões associados à temperatura e latitude se misturam com aqueles associados à altitude e longitude. Em grande parte, isto se deve certamente ao fato de as áreas de maior altitude (baixo-montanas e alto-montanas) ocorrerem principalmente no sul da região, no caso das florestas ombrófilas, e no oeste, no caso das florestas semidecíduas. Isto se reflete na situação de todas as florestas de maior altitude no lado esquerdo do diagrama, associadas a longitudes maiores e temperaturas mais baixas. Neste setor do diagrama, a distribuição nortesul das áreas pertencentes às duas classes altitudinais é percebida somente no segundo eixo de ordenação. A importância da altitude na diferenciação florísticas de florestas ombrófilas e semidecíduas do domínio Atlântico já foi documentada e bem discutida para outras regiões do Brasil, como o Nordeste (Ferraz et al. 2004), o estado de São Paulo (Salis et al. 1995; Torres et al. 1997; Scudeller et al. 2001), o sul de Minas Gerais (OliveiraFilho et al. 1994) e o Sudeste do país (OliveiraFilho \& Fontes 2000). O presente trabalho, portanto, reafirma os mesmos achados e os estende a uma região para a qual análises florísticas da flora arbórea da floresta atlântica sensu lato careciam de maiores informações. Salientamos, neste ponto, que perspectivas de análises futuras da flora da mesma região apontam para a carência de informações sobre as florestas de maiores altitudes do maciço do Caparaó, tanto em sua vertente continental, em Minas Gerais, como na vertente oceânica, no Espírito Santo. 


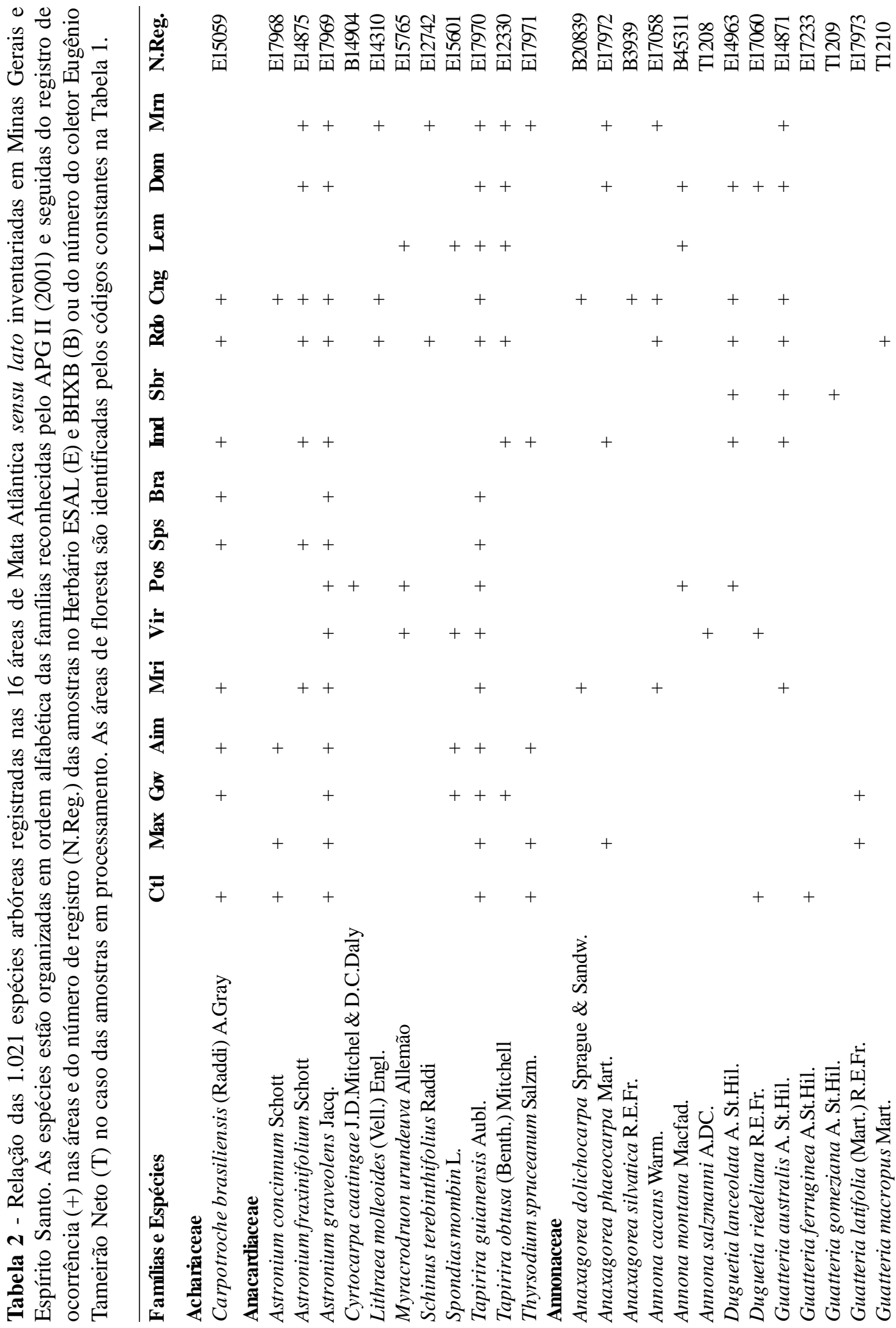

Rodriguésia 56 (87): 185-235. 2005 


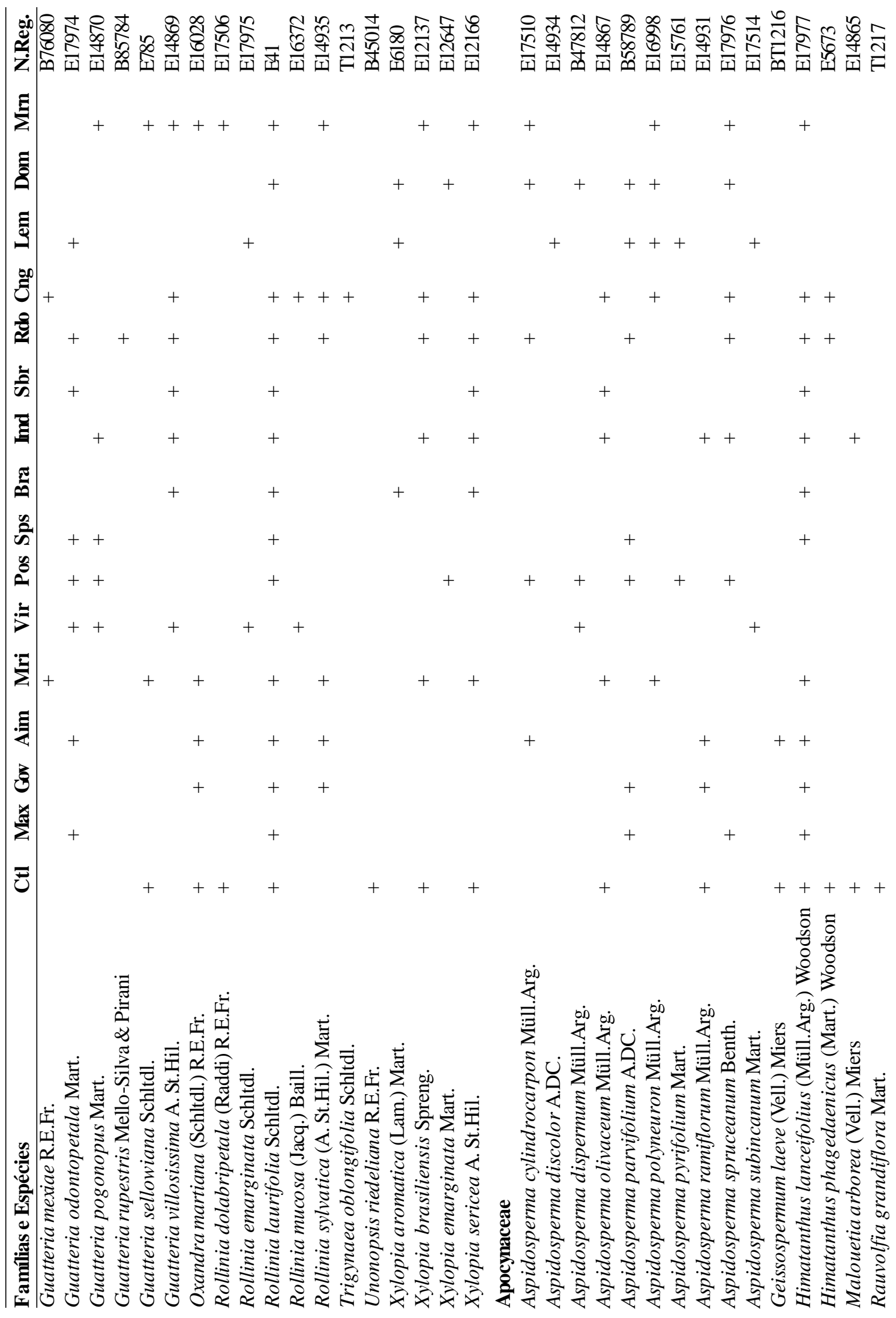




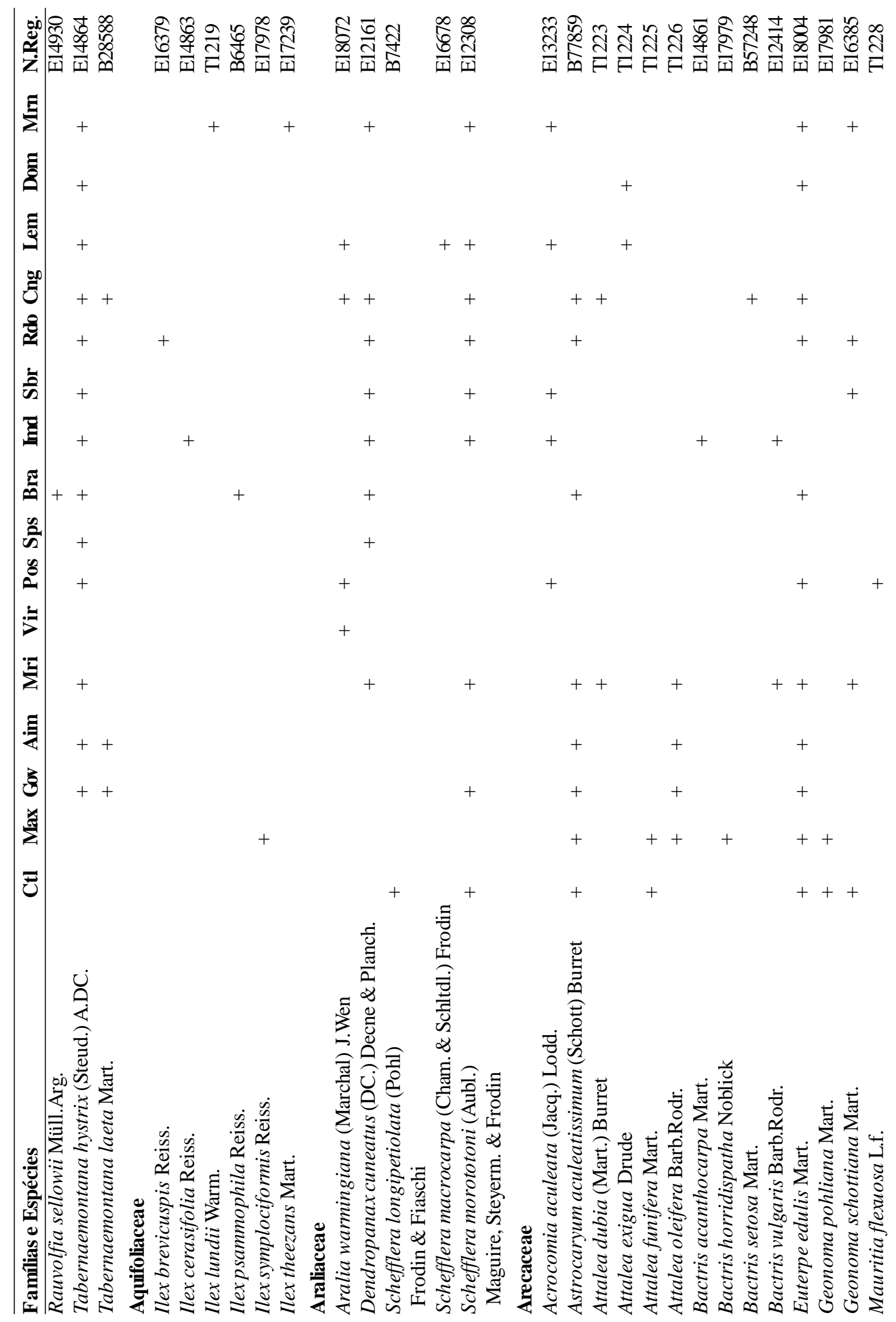

Rodriguésia 56 (87): 185-235. 2005 


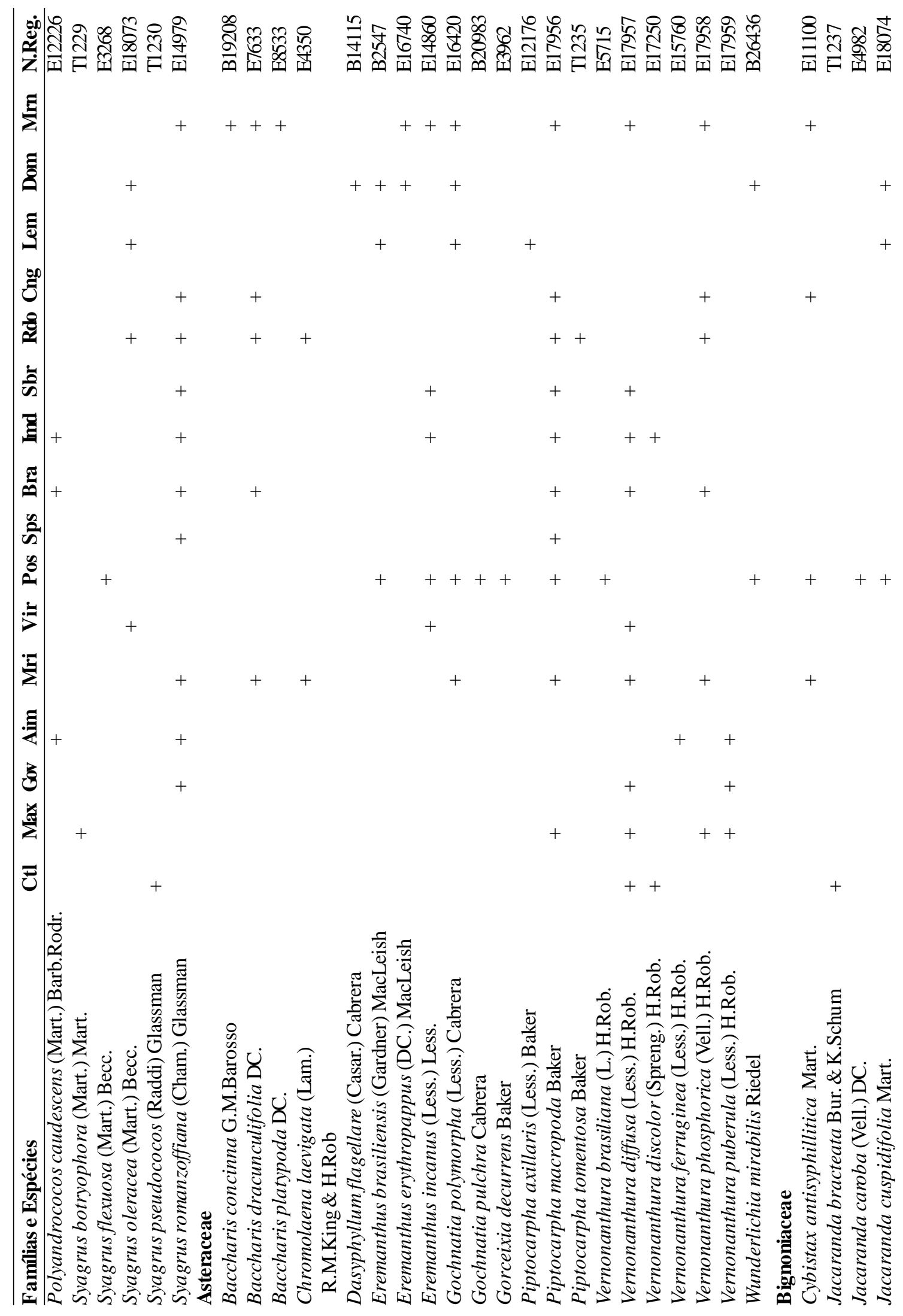




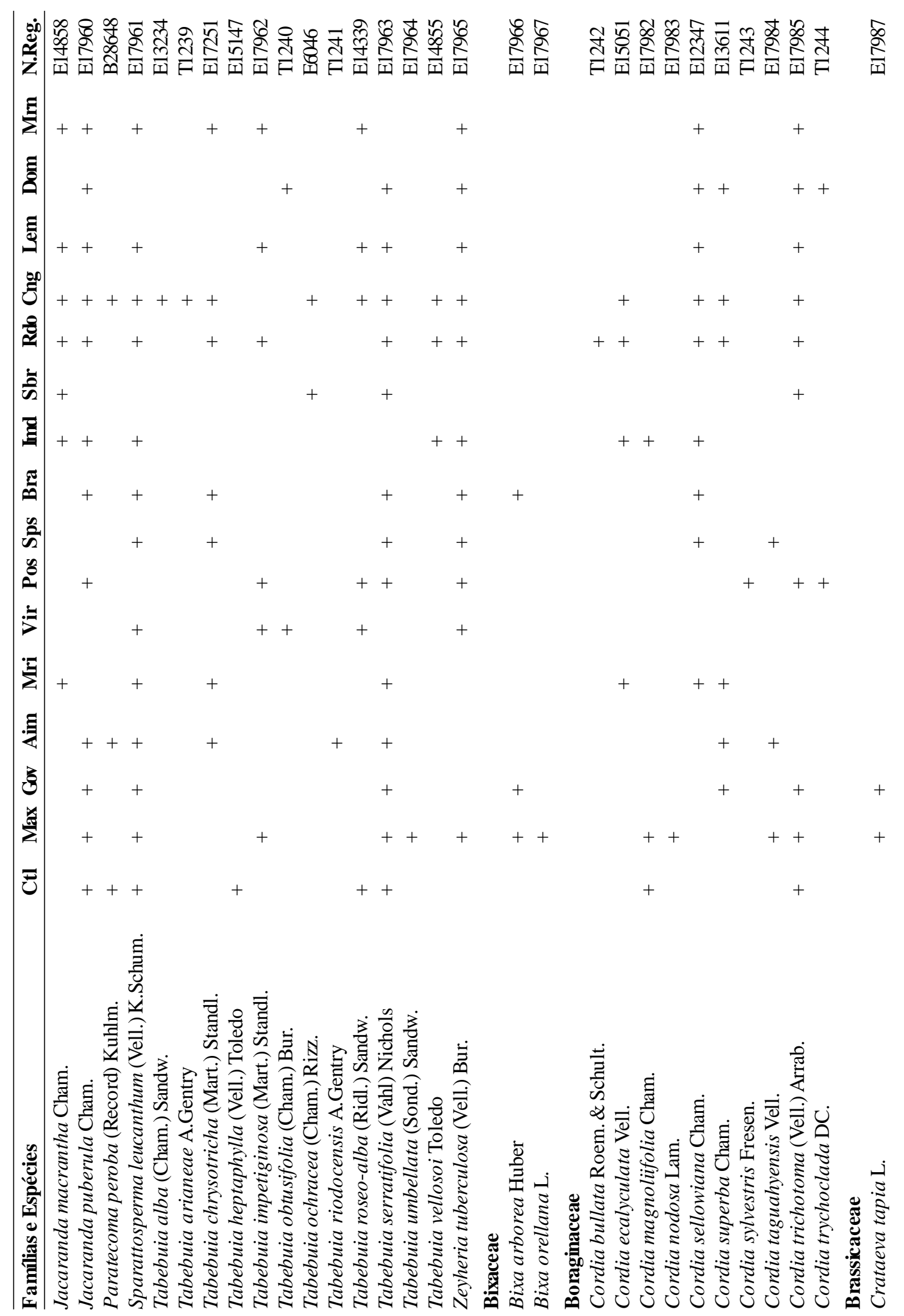

Rodriguésia 56 (87): 185-235. 2005 


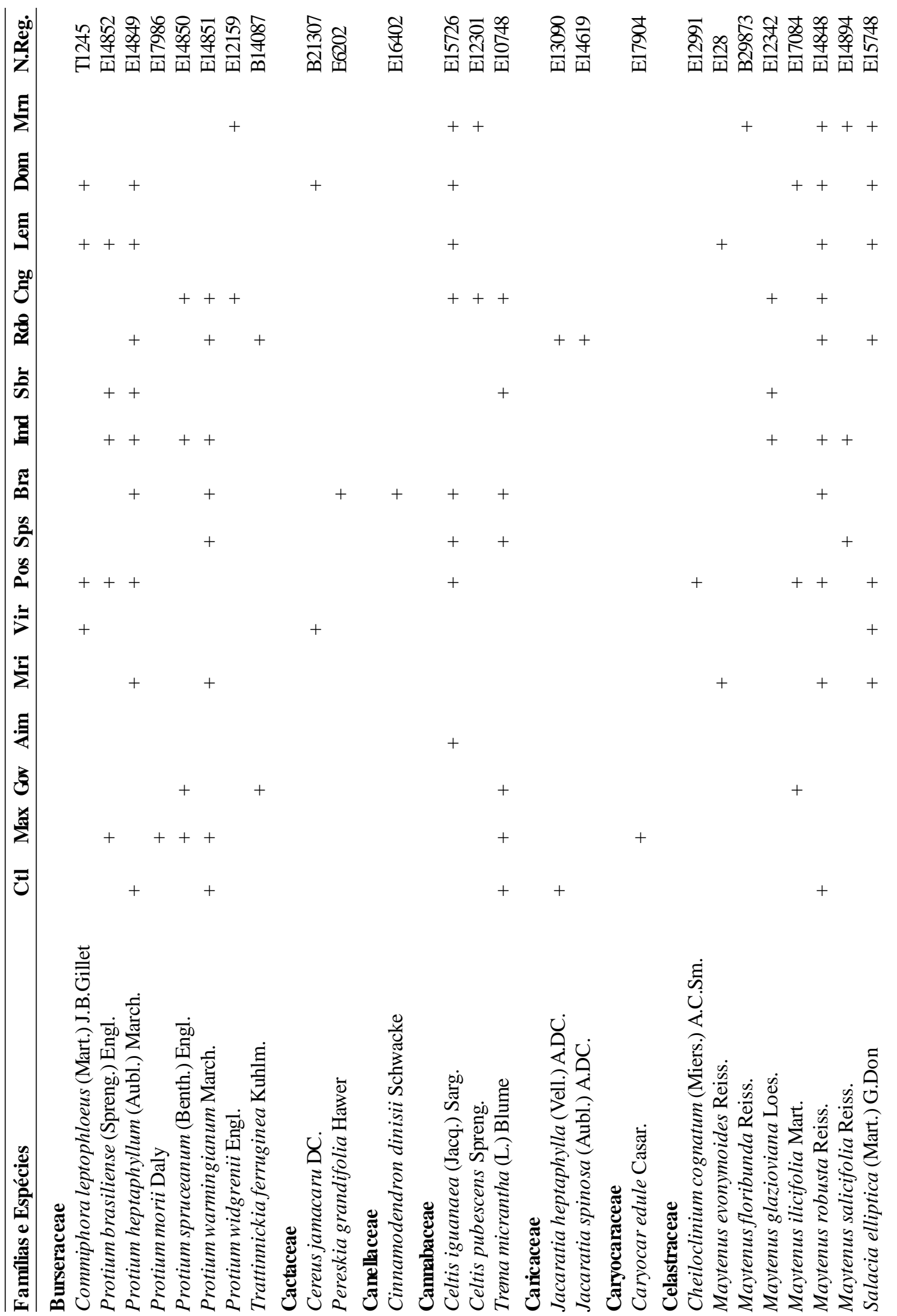




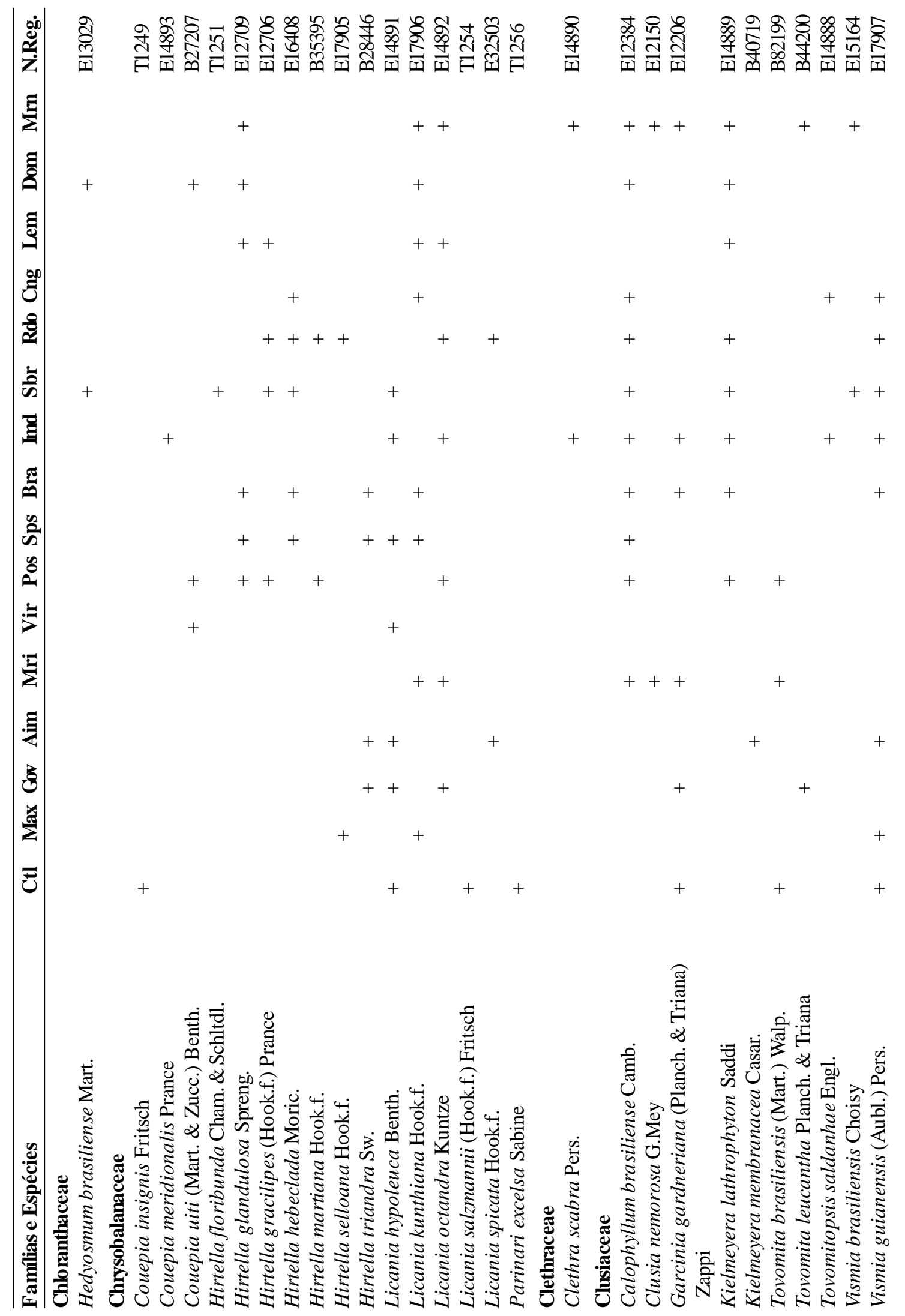

Rodriguésia 56 (87): 185-235. 2005 


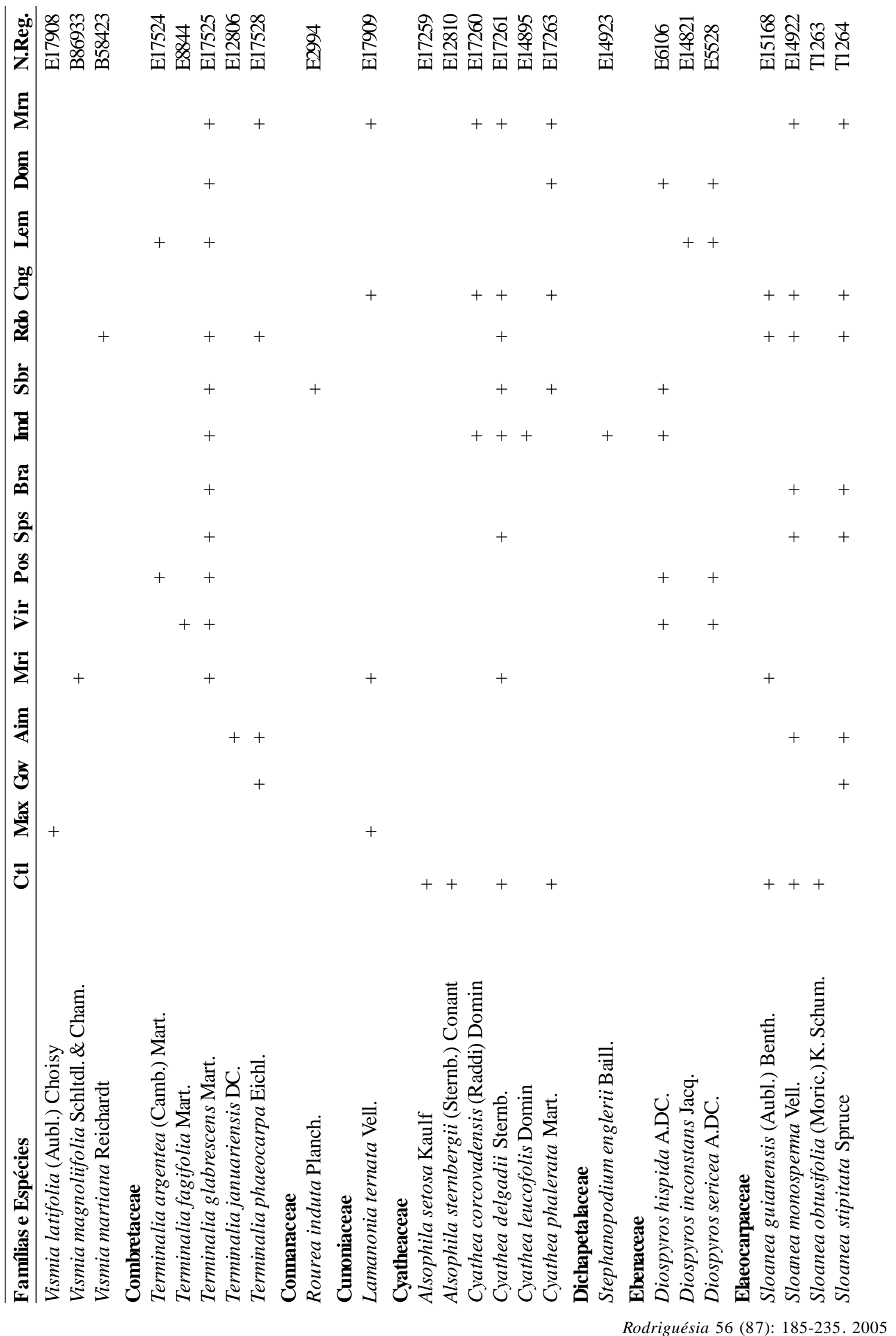




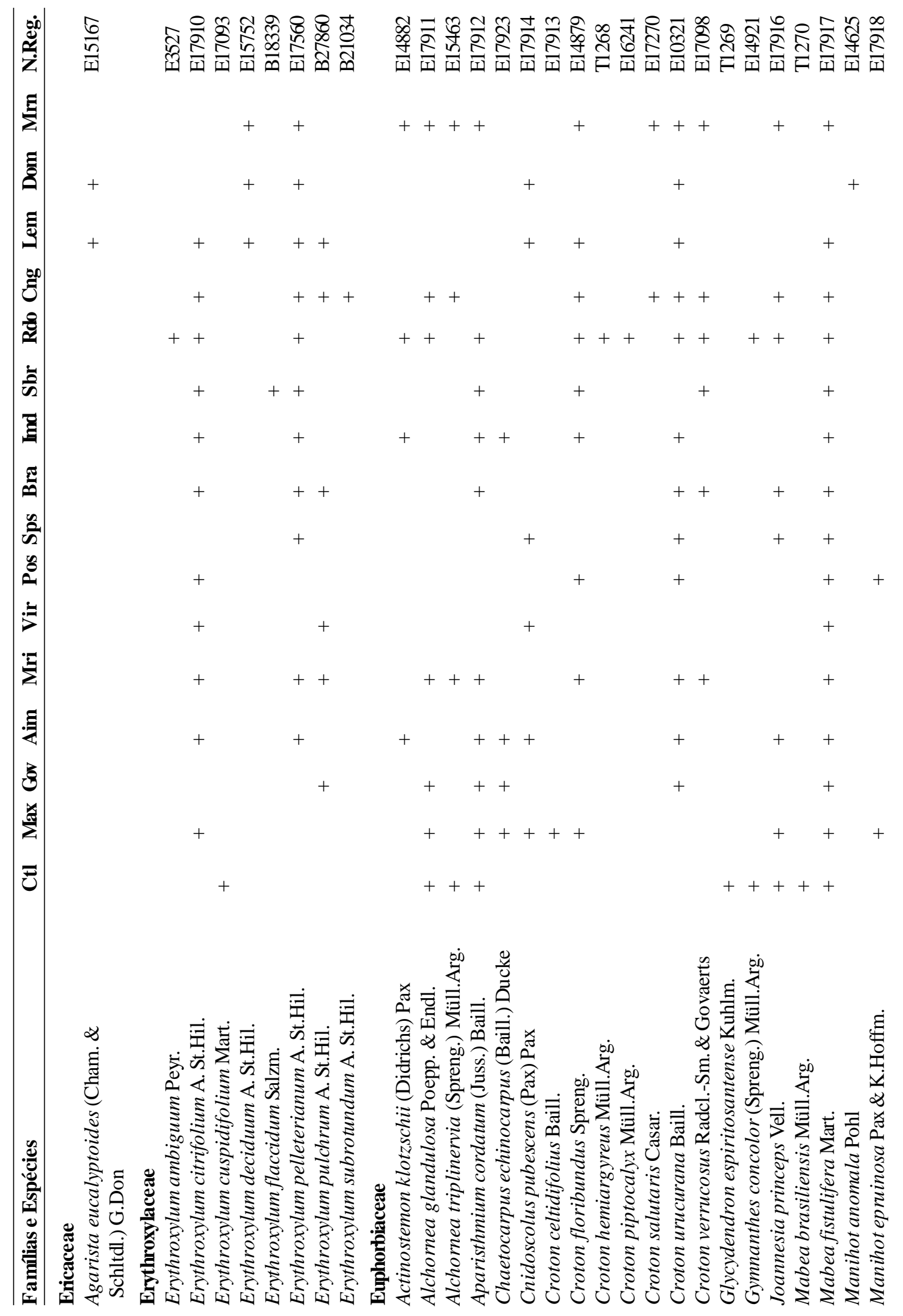

Rodriguésia 56 (87): 185-235. 2005 


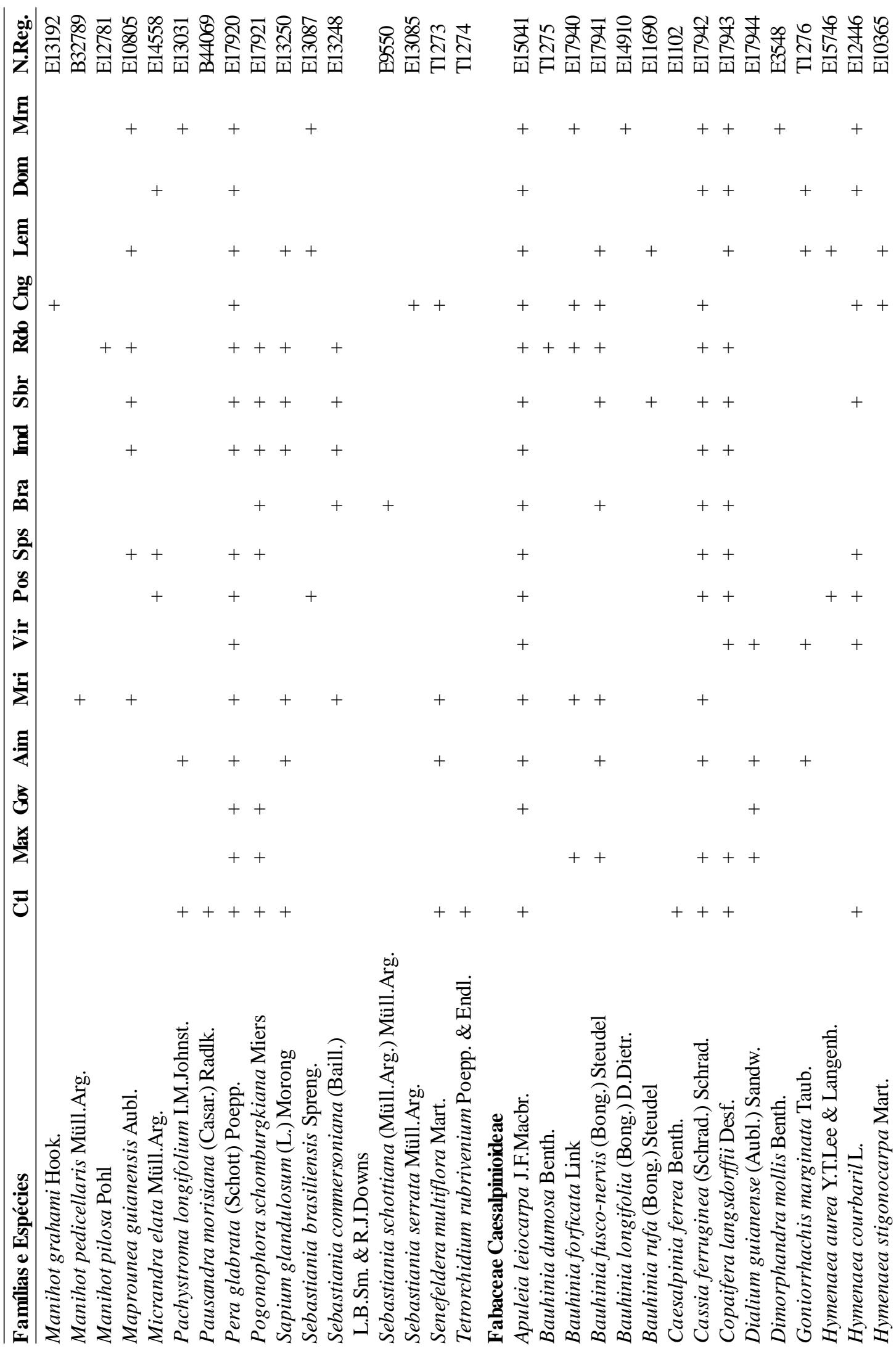

Rodriguésia 56 (87): 185-235. 2005 


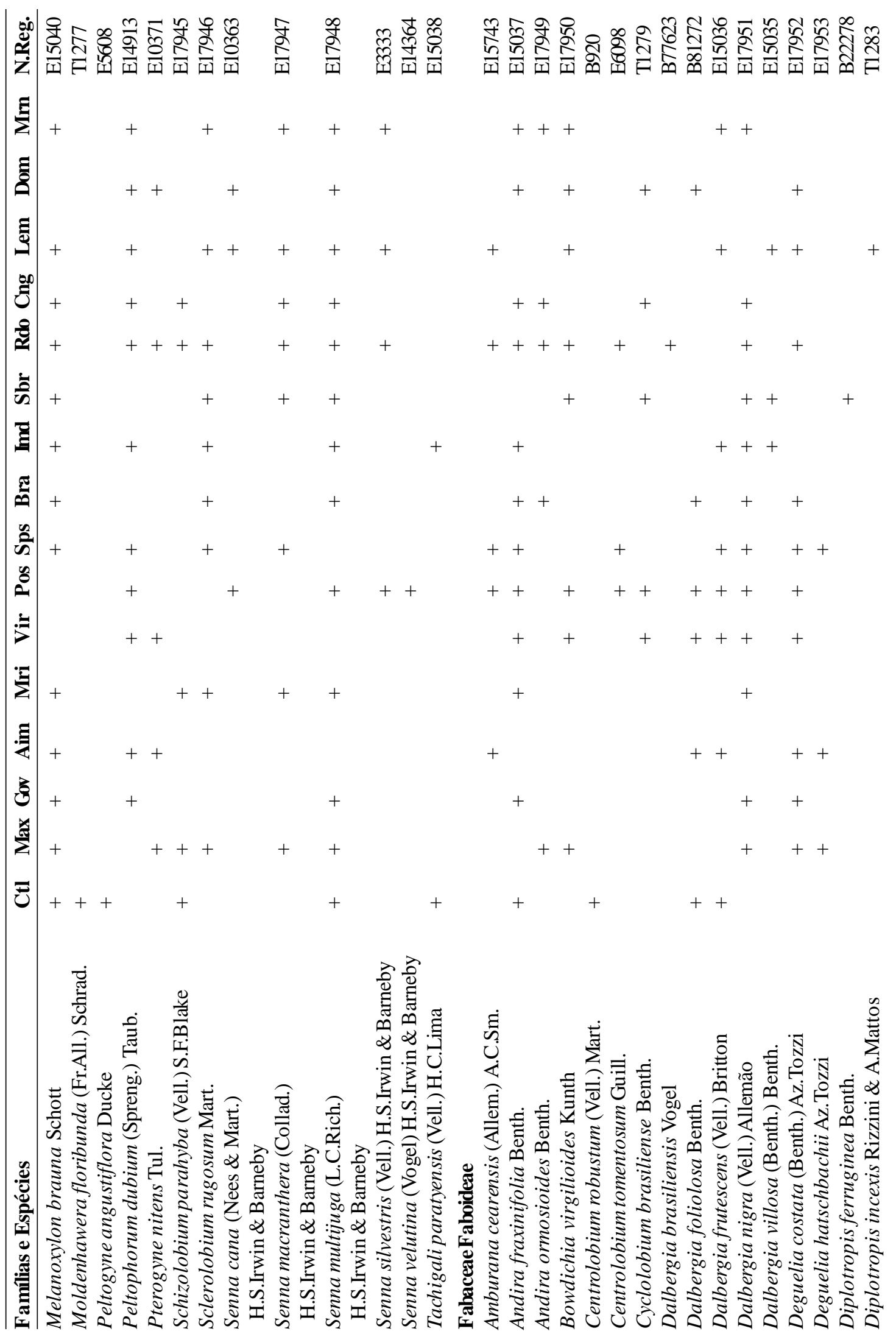

Rodriguésia 56 (87): 185-235. 2005 


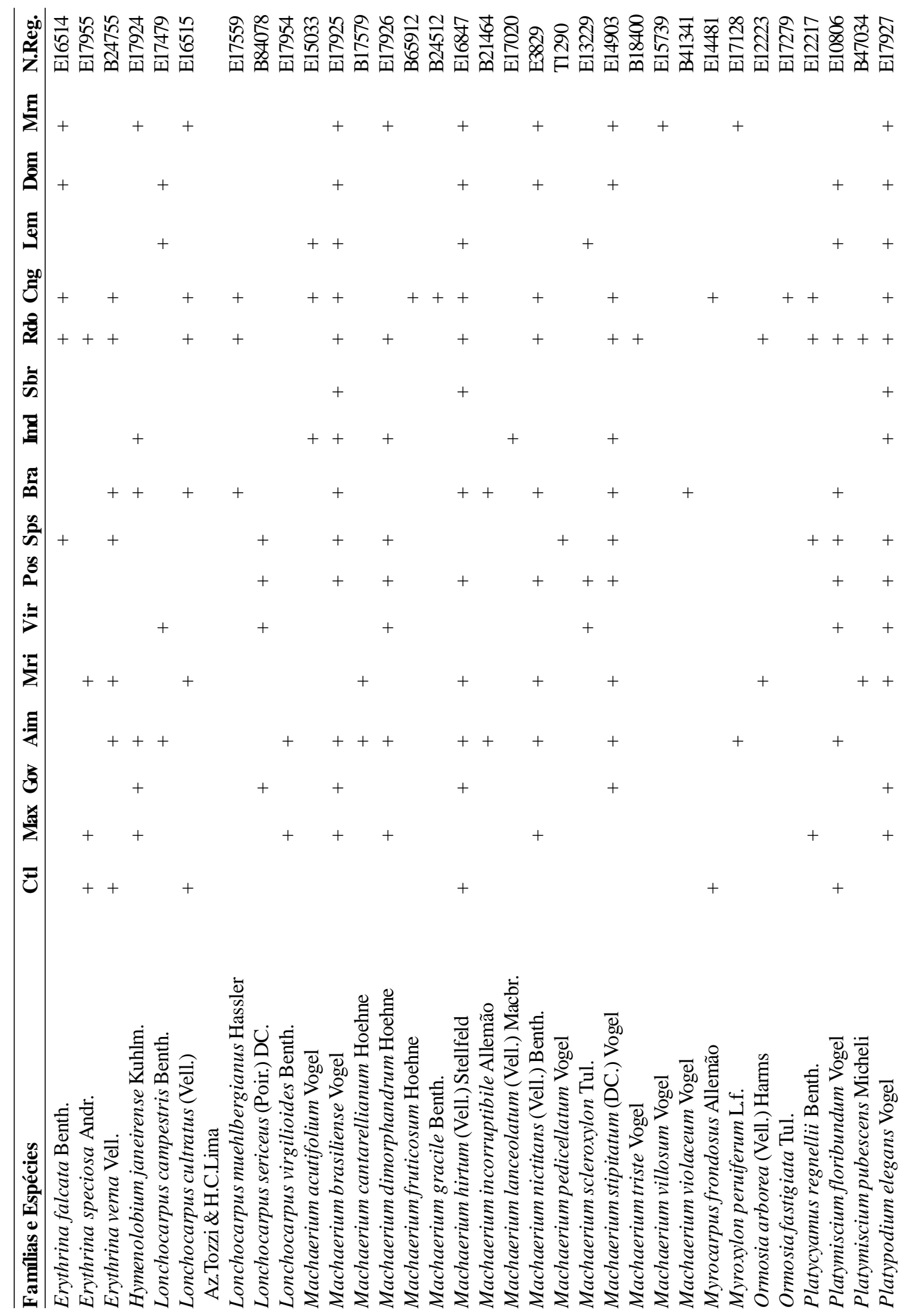




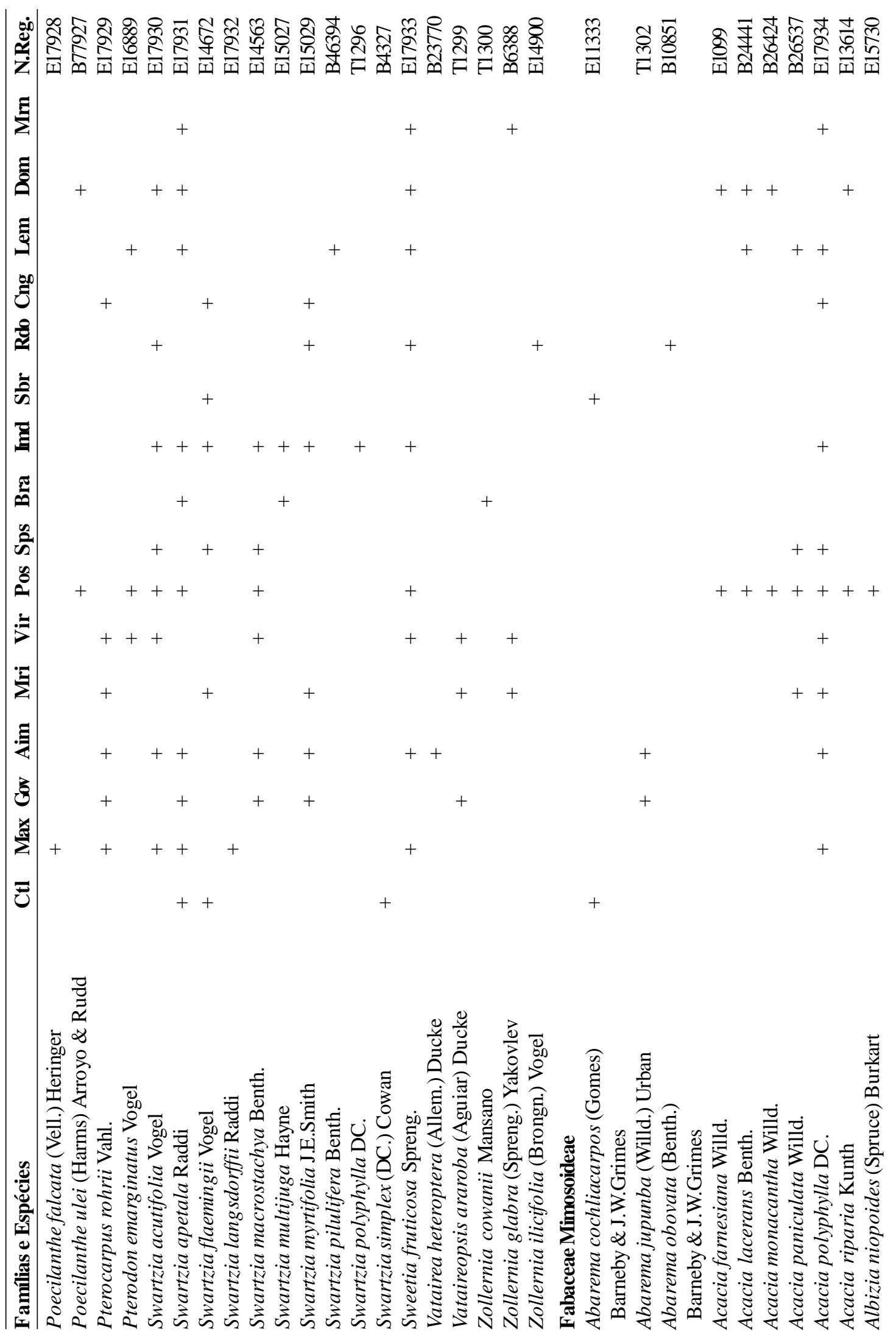

Rodriguésia 56 (87): 185-235. 2005 

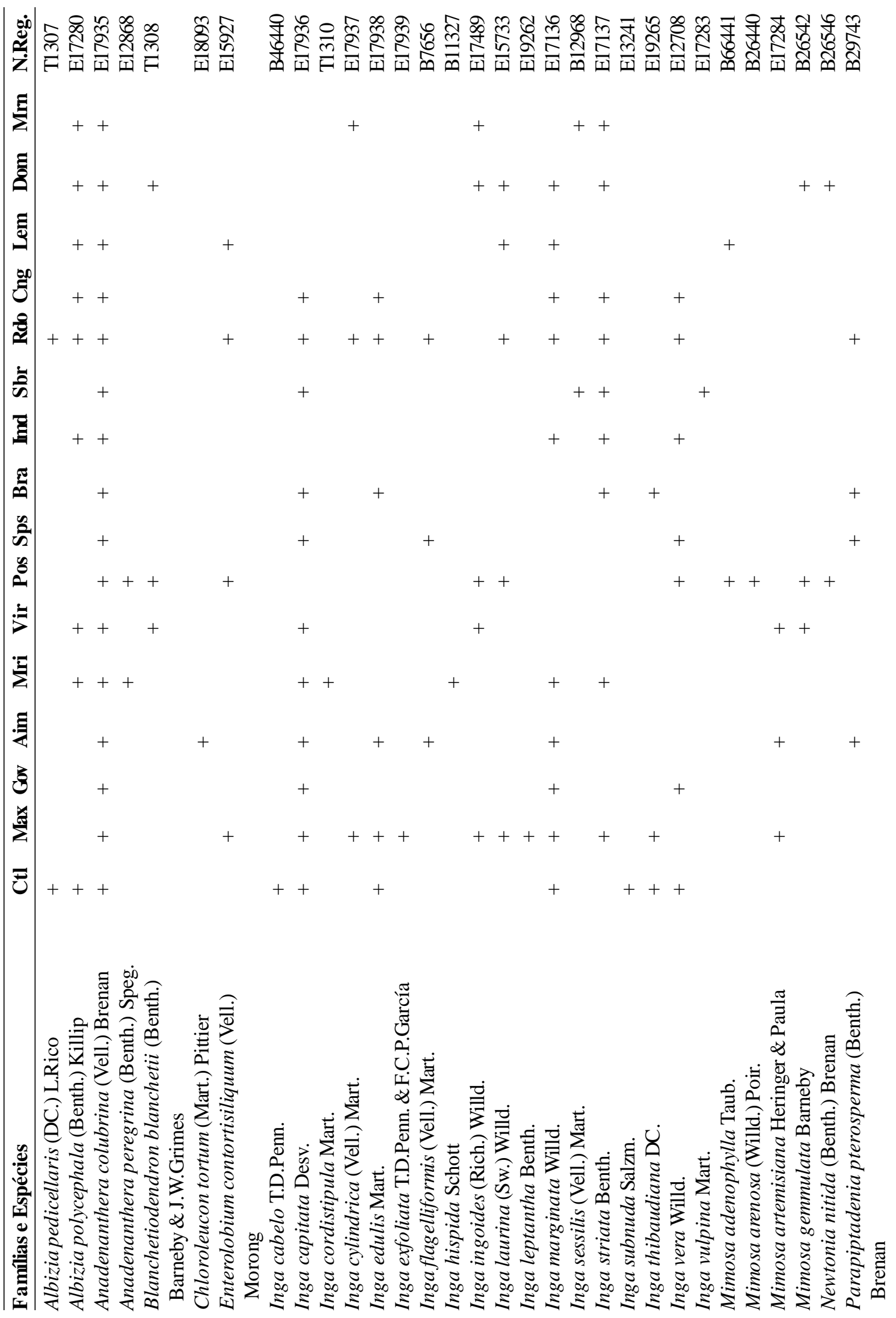


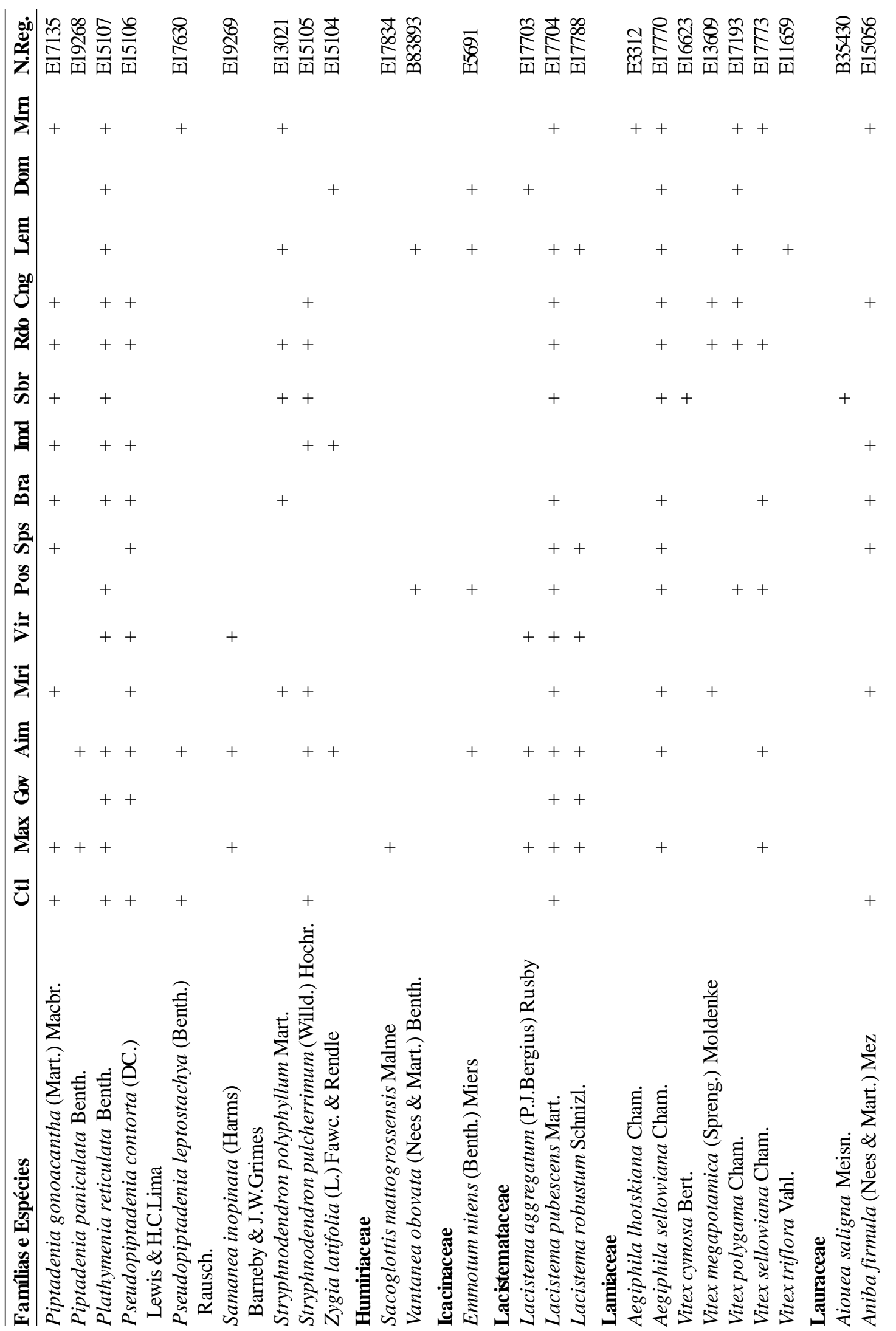

Rodriguésia 56 (87): 185-235. 2005 


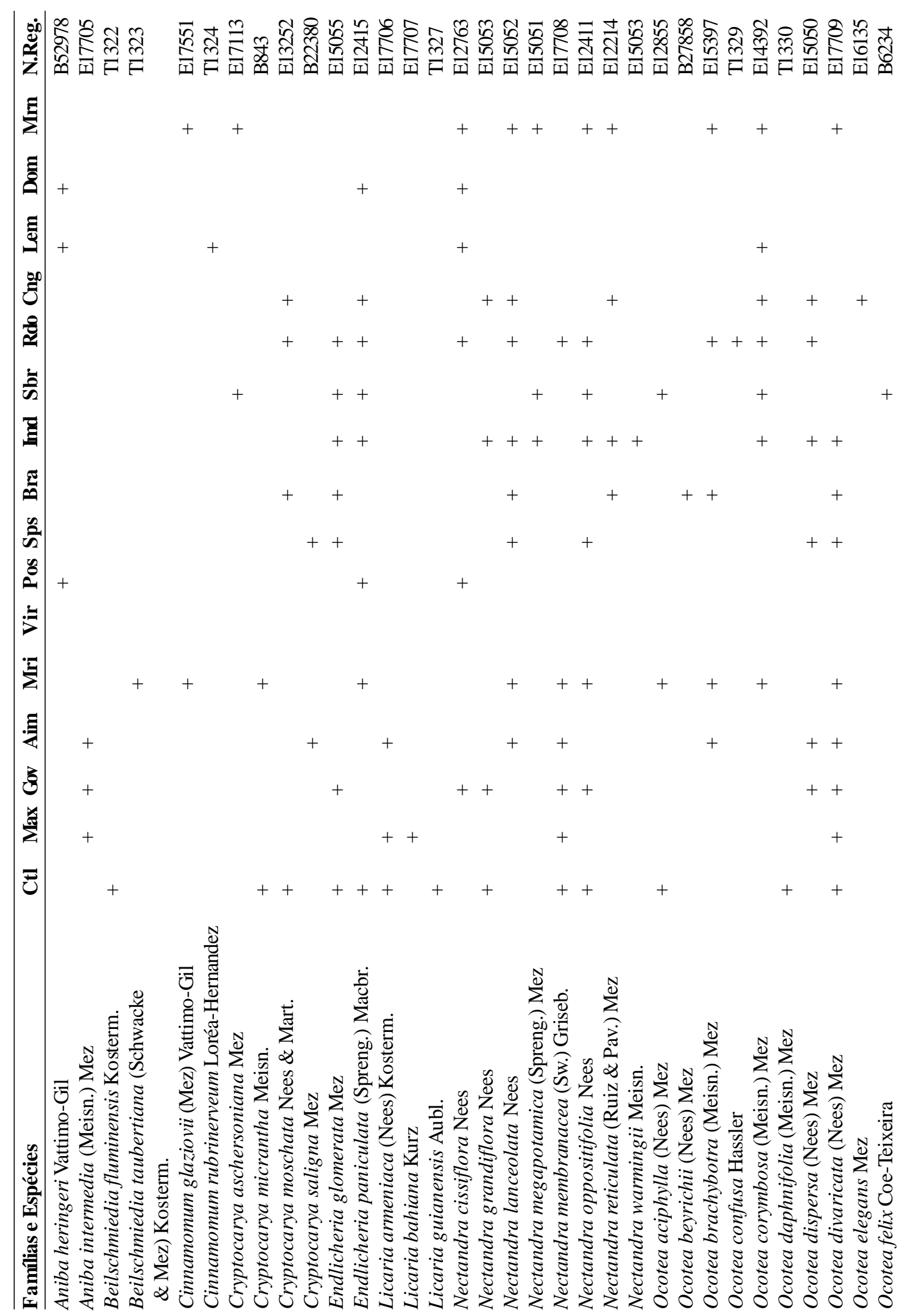




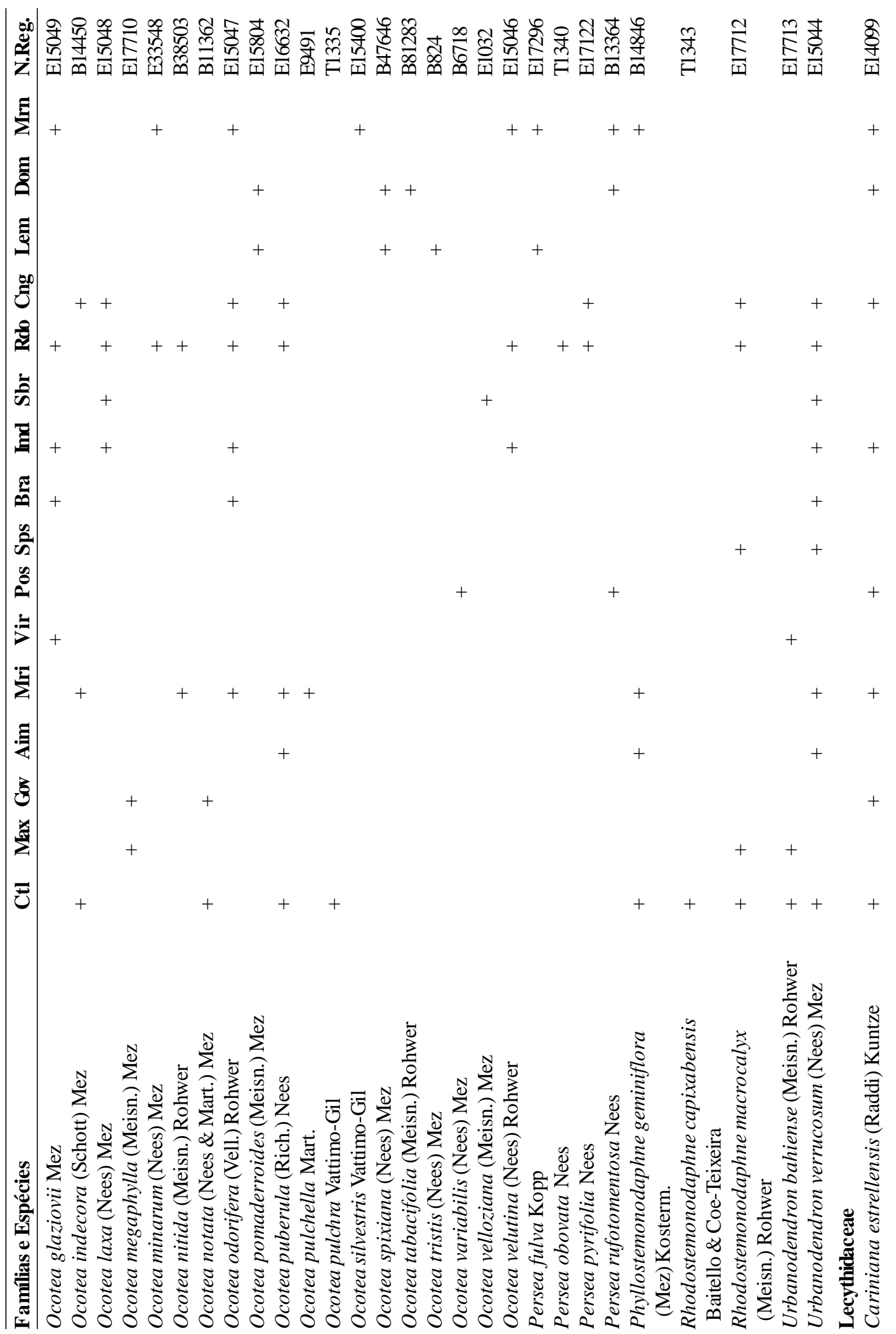

Rodriguésia 56 (87): 185-235. 2005 


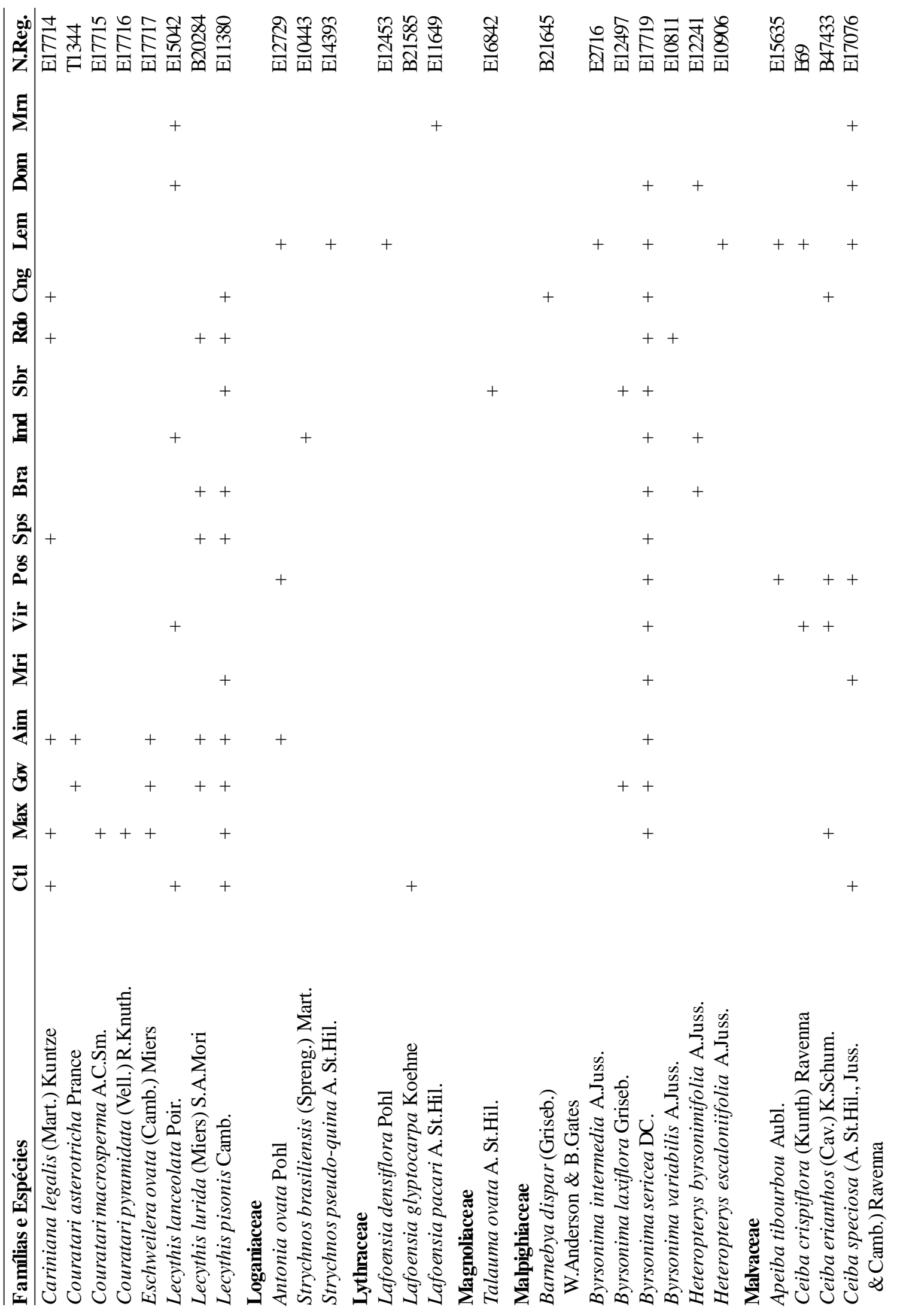




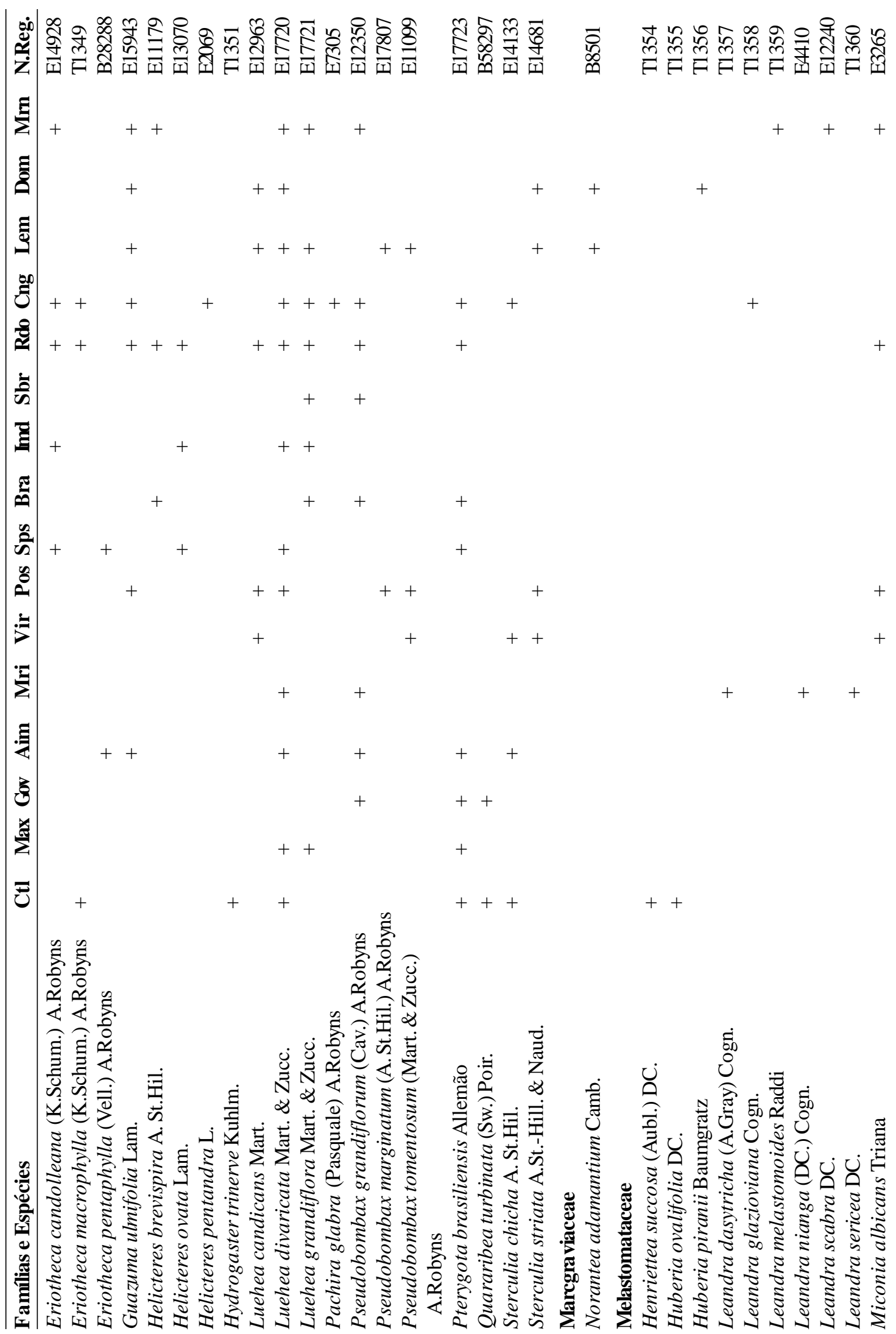

Rodriguésia 56 (87): 185-235. 2005 


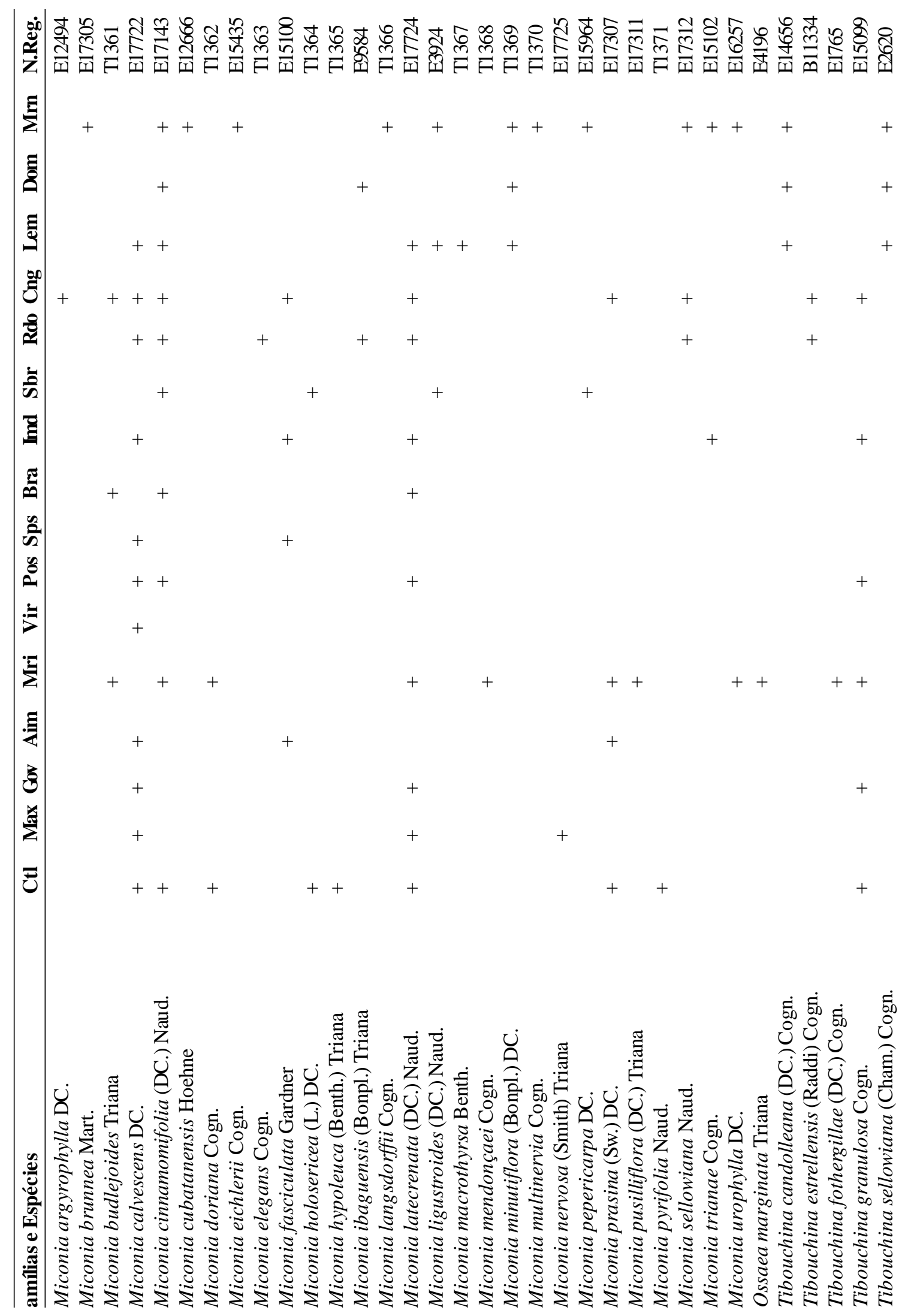




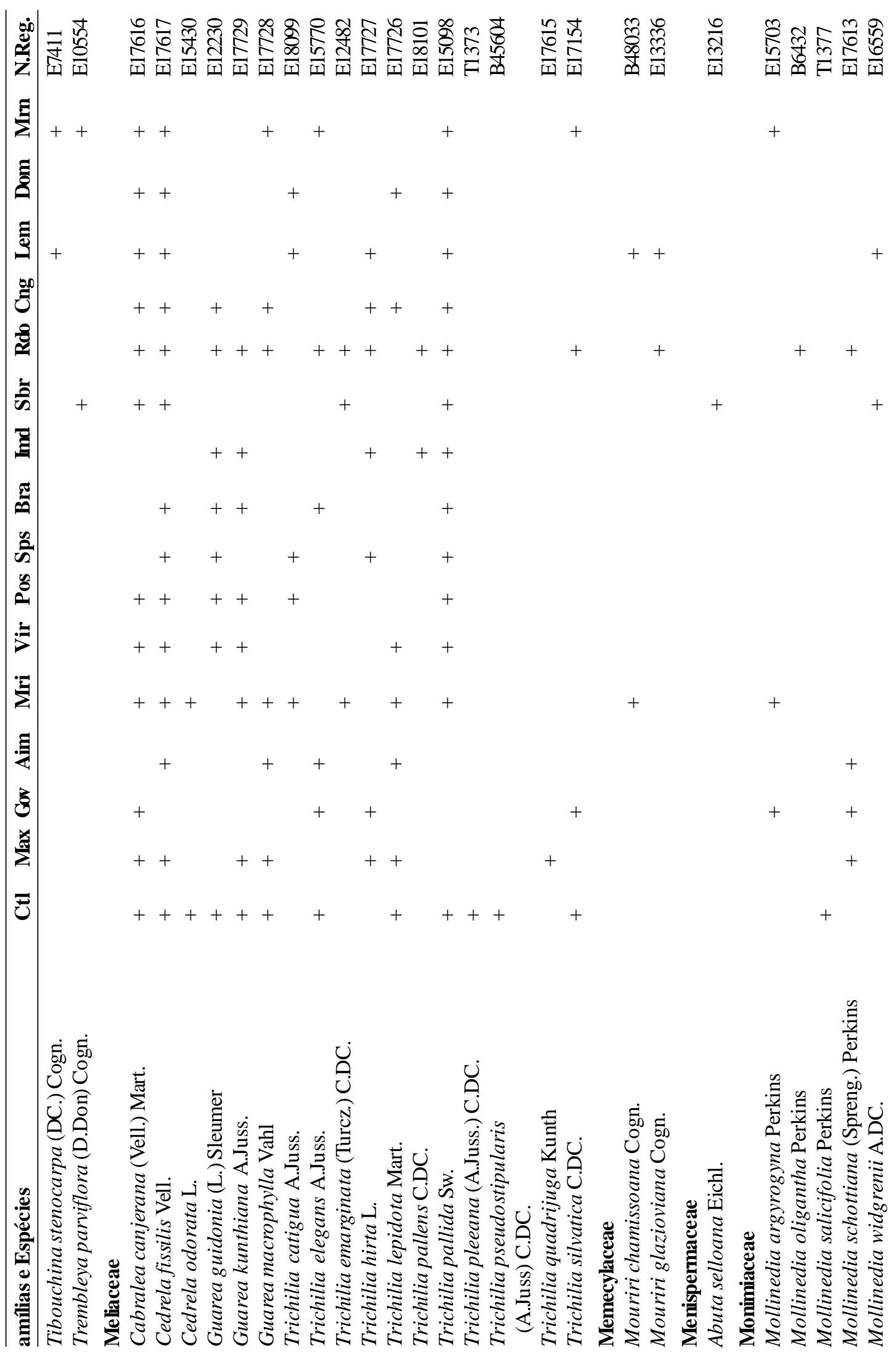

Rodriguésia 56 (87): 185-235. 2005 


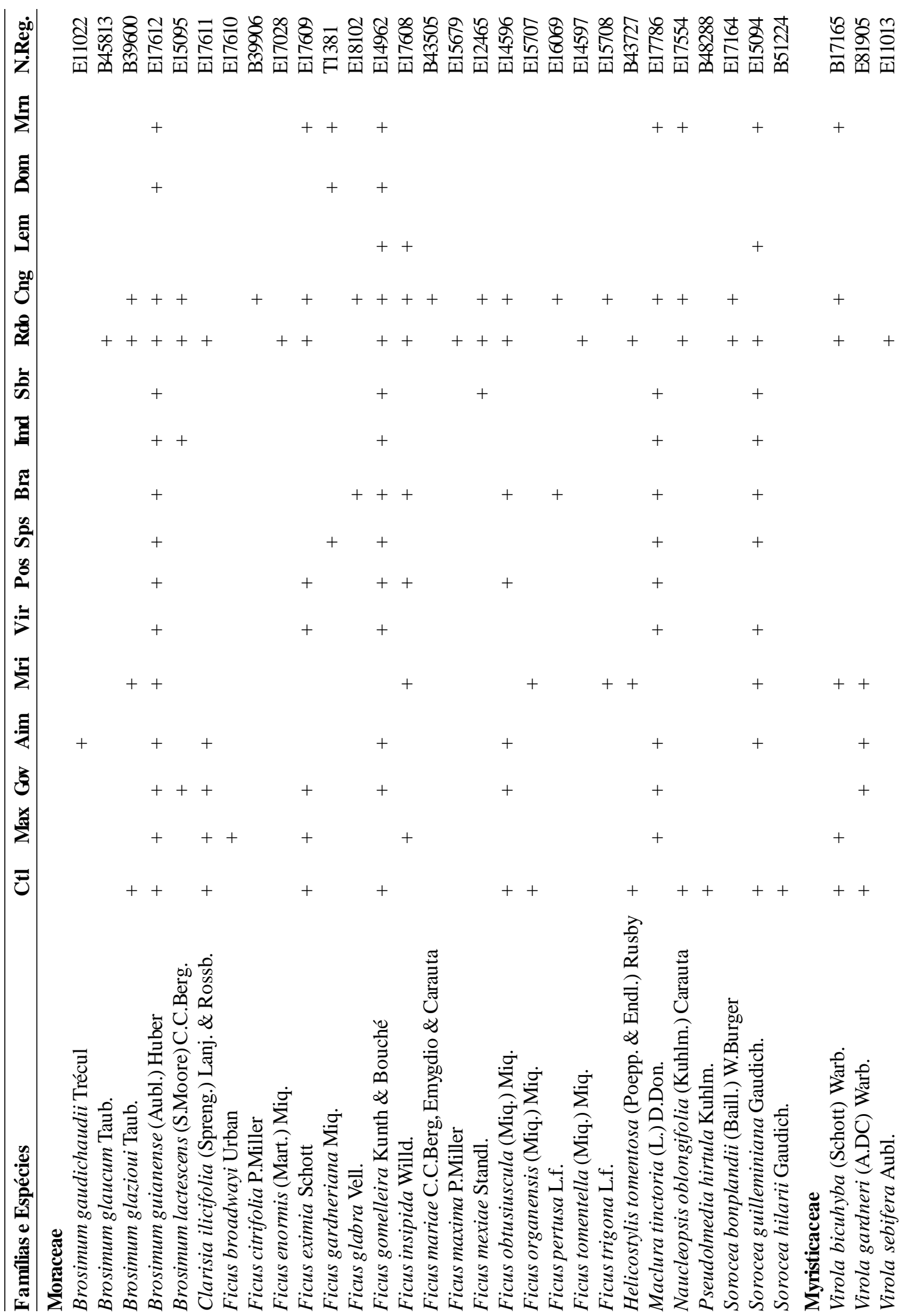




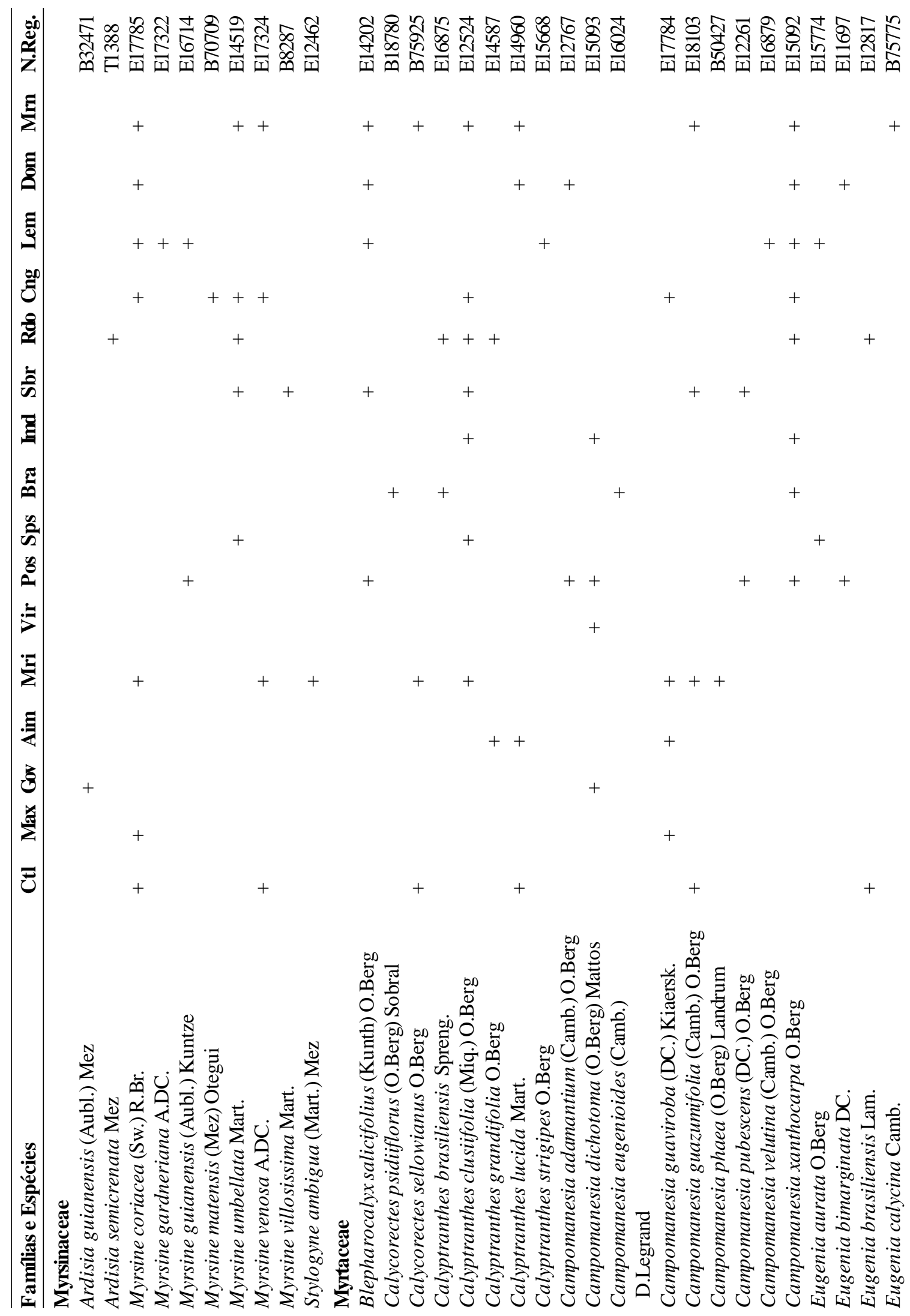

Rodriguésia 56 (87): 185-235. 2005 

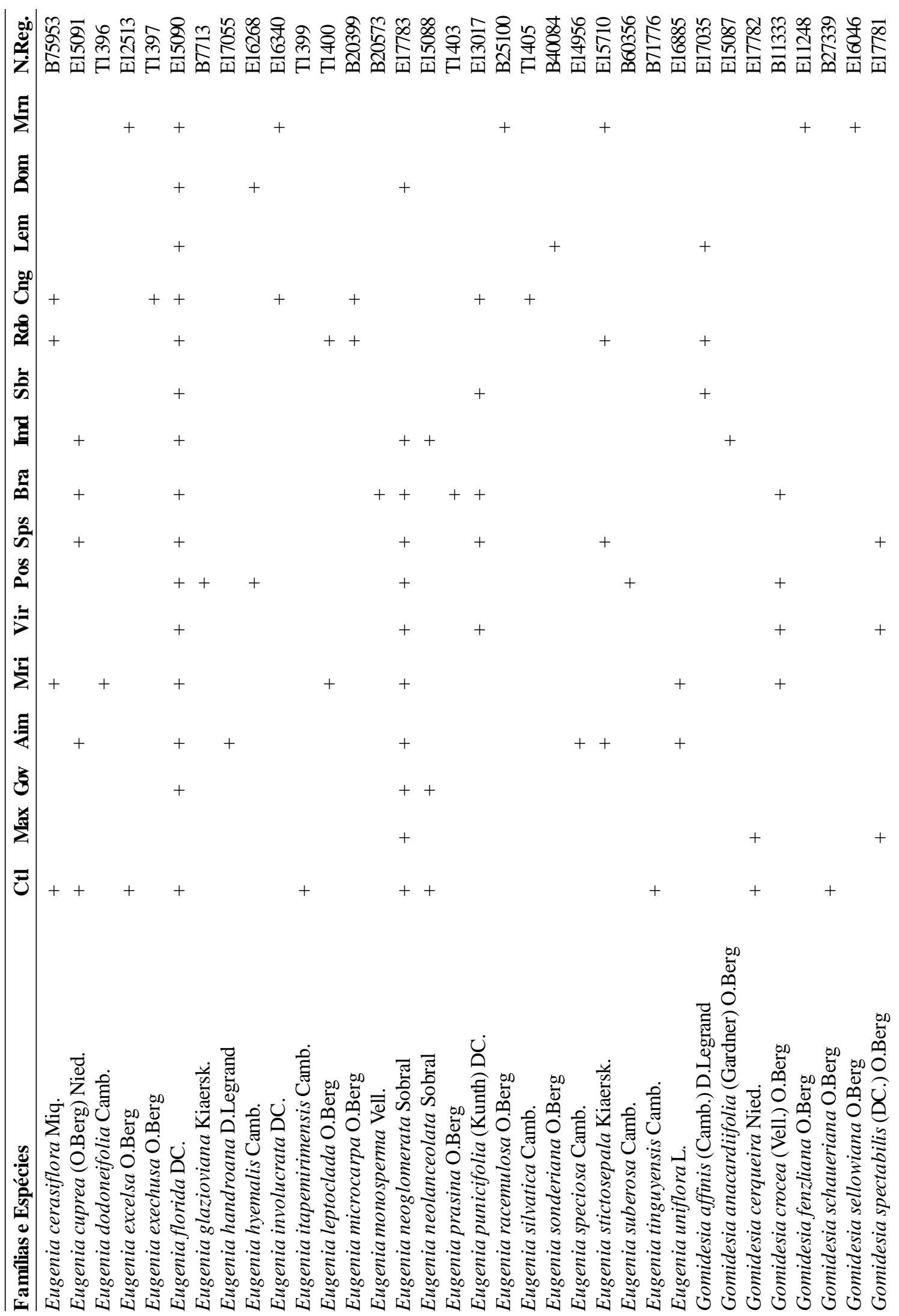


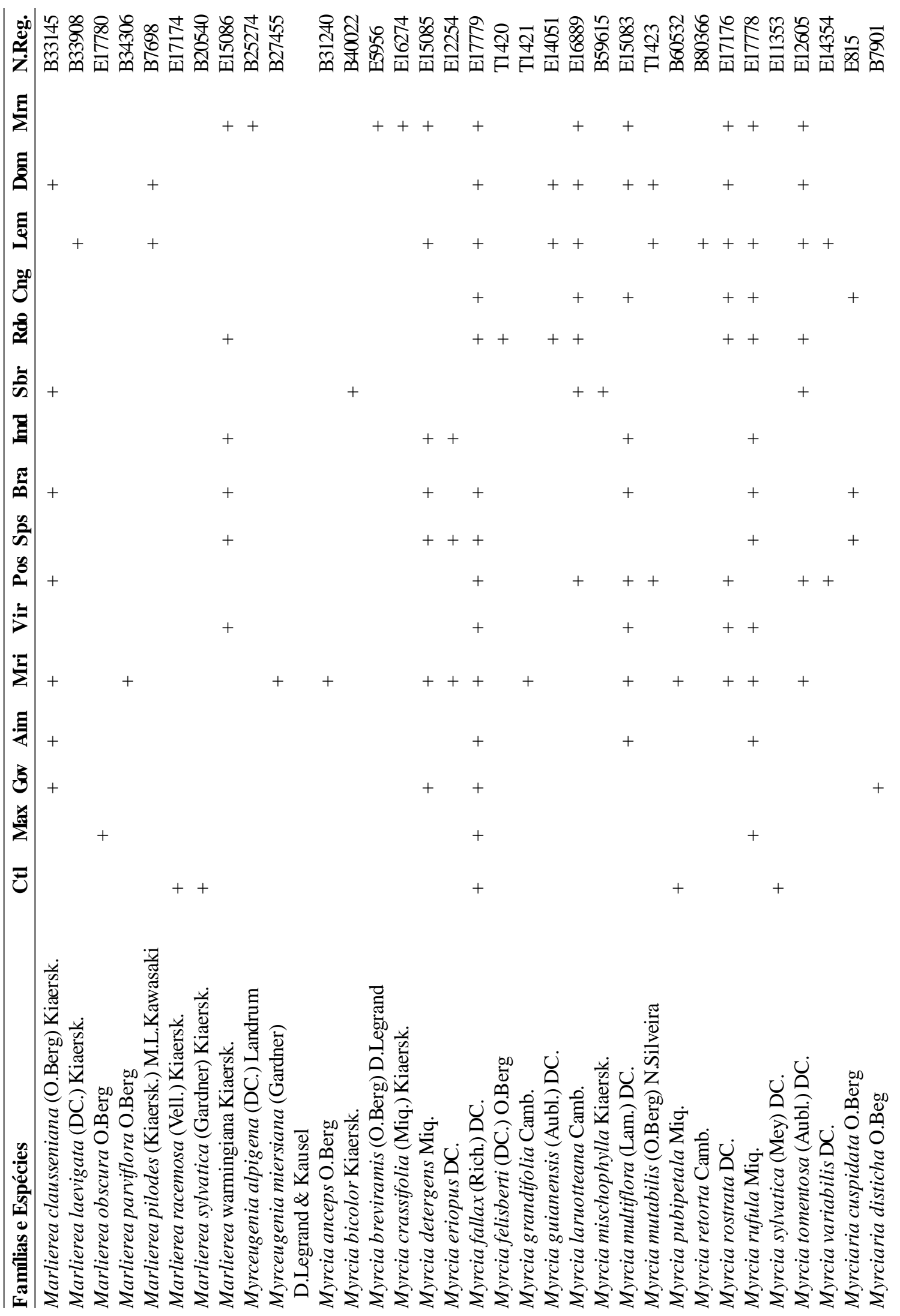

Rodriguésia 56 (87): 185-235. 2005 


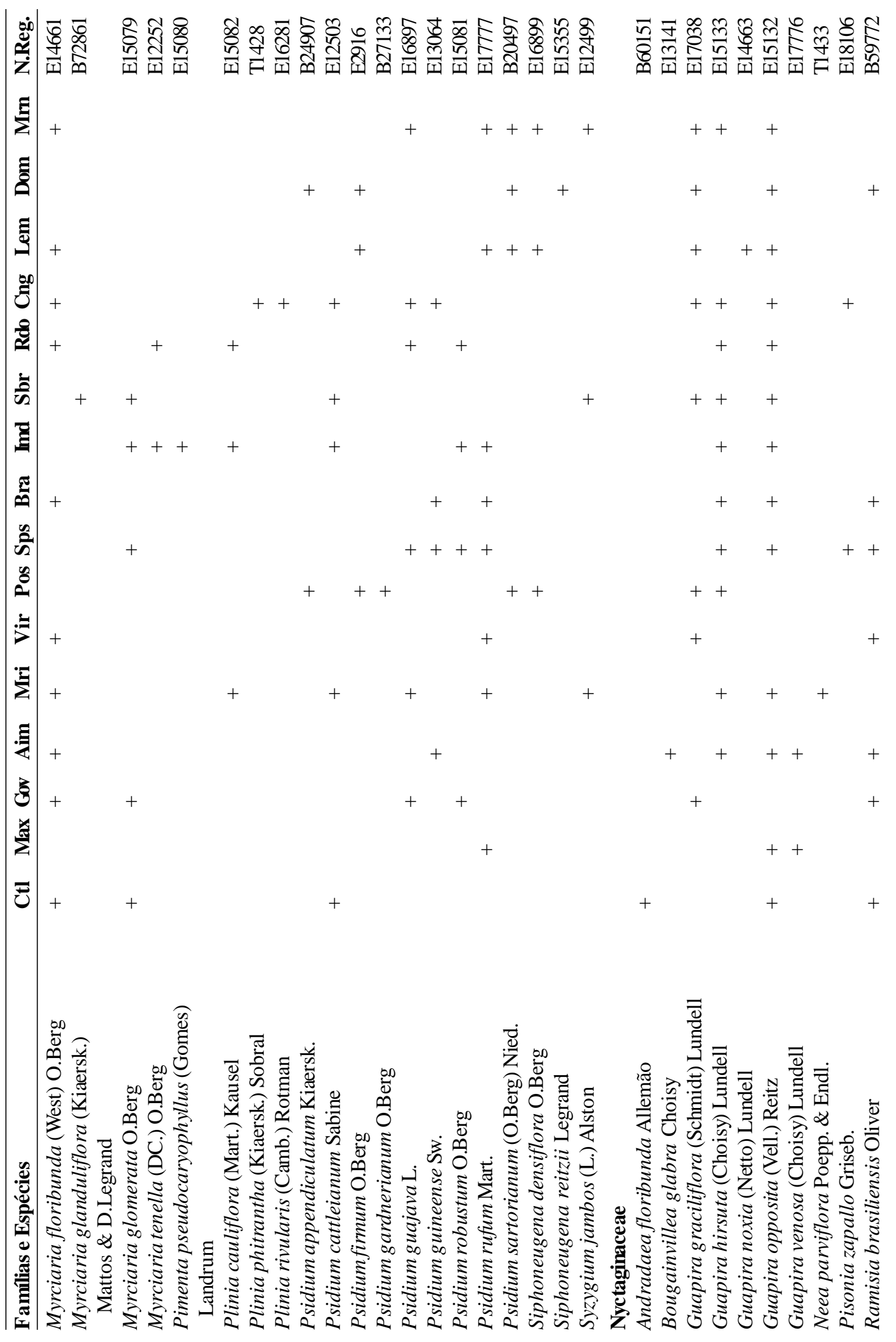

Rodriguésia 56 (87): 185-235. 2005 


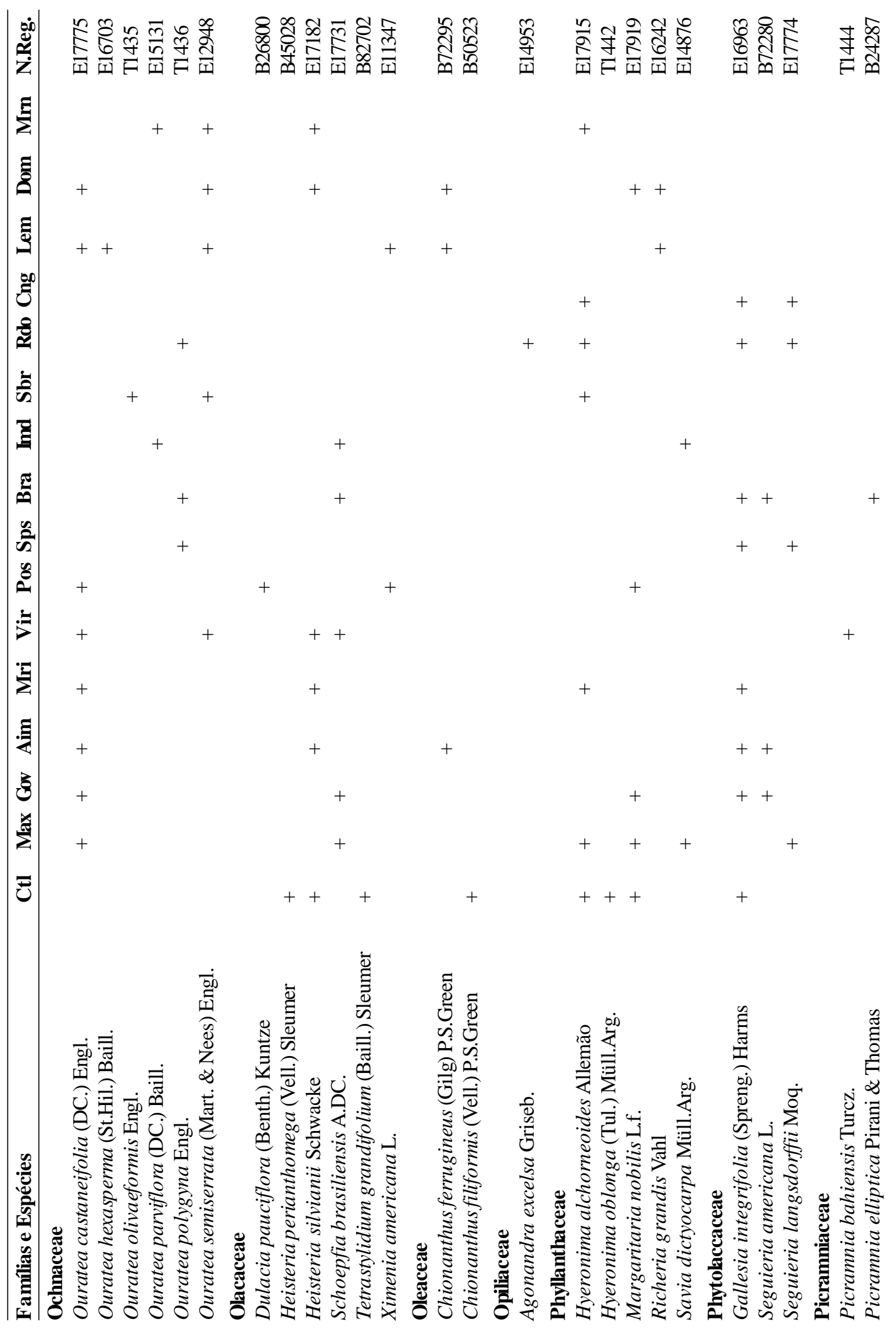

Rodriguésia 56 (87): 185-235. 2005 


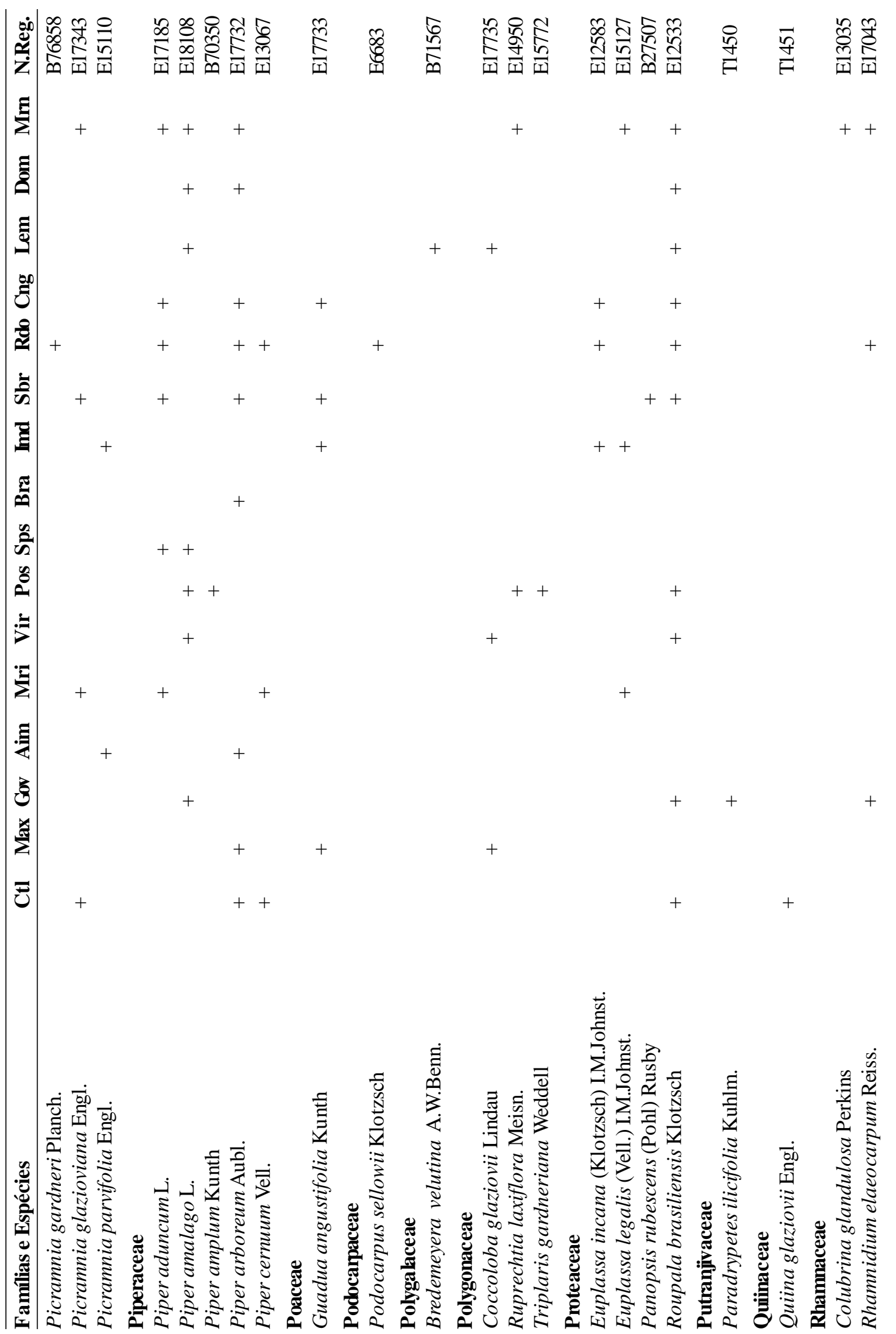




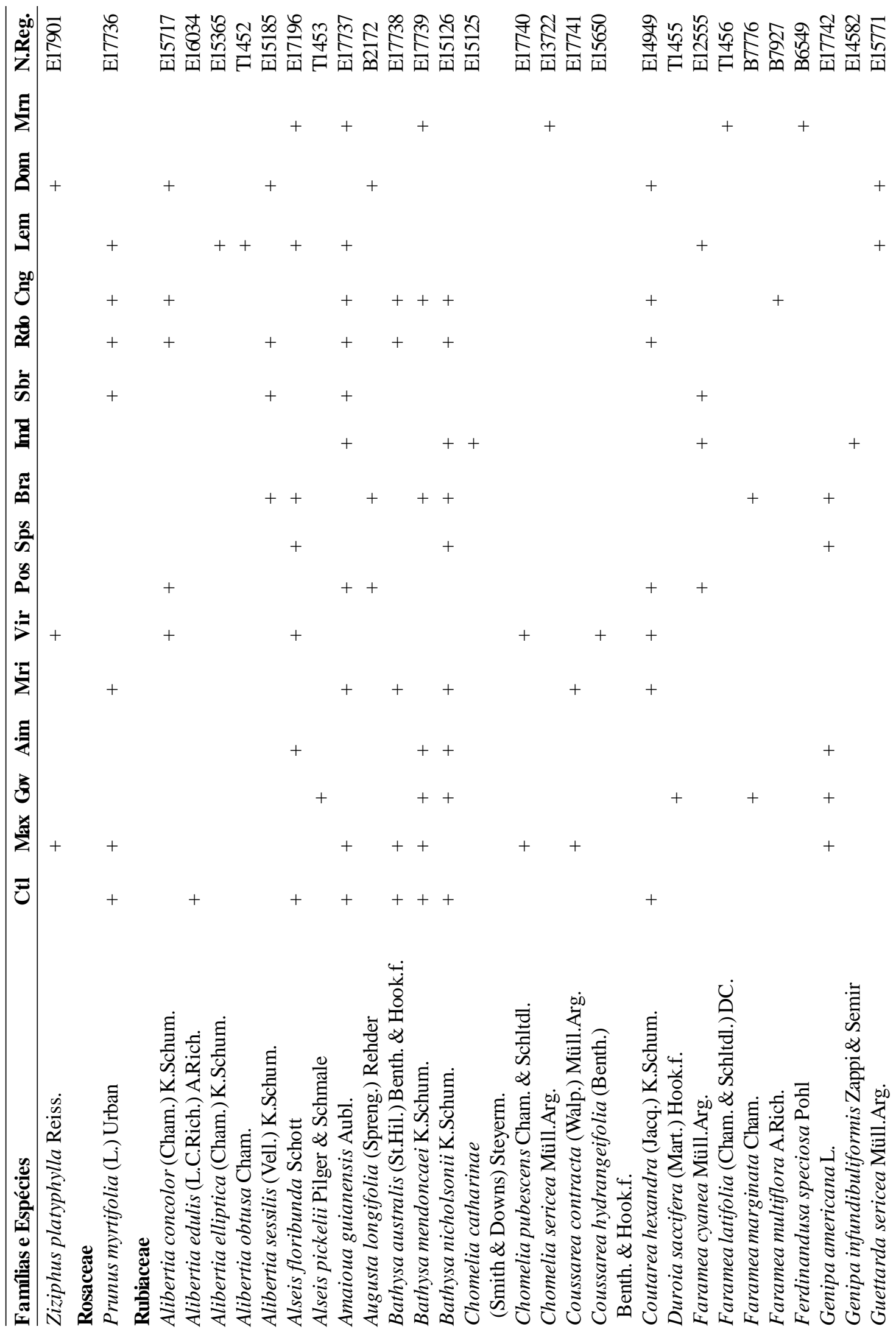

Rodriguésia 56 (87): 185-235. 2005 


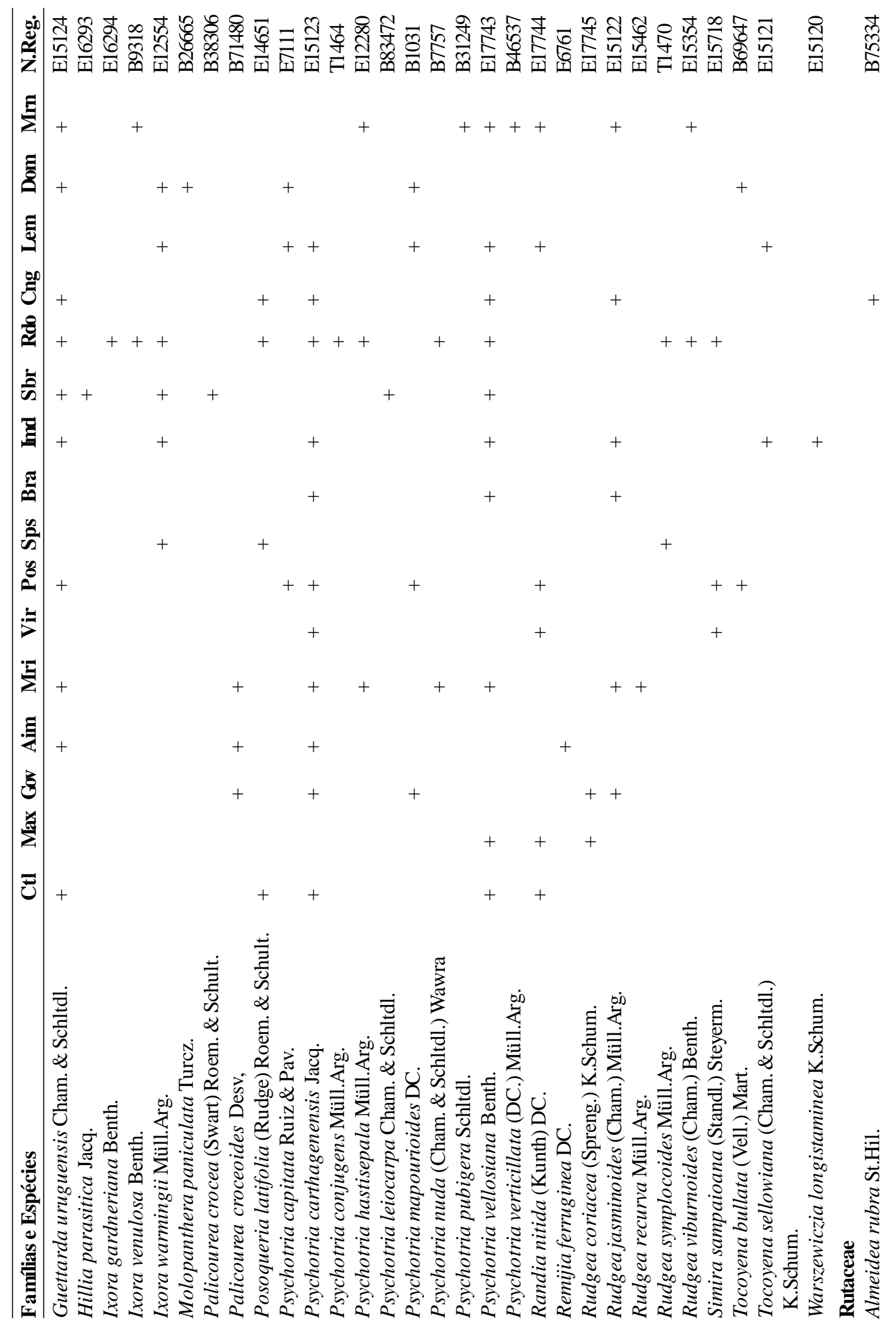




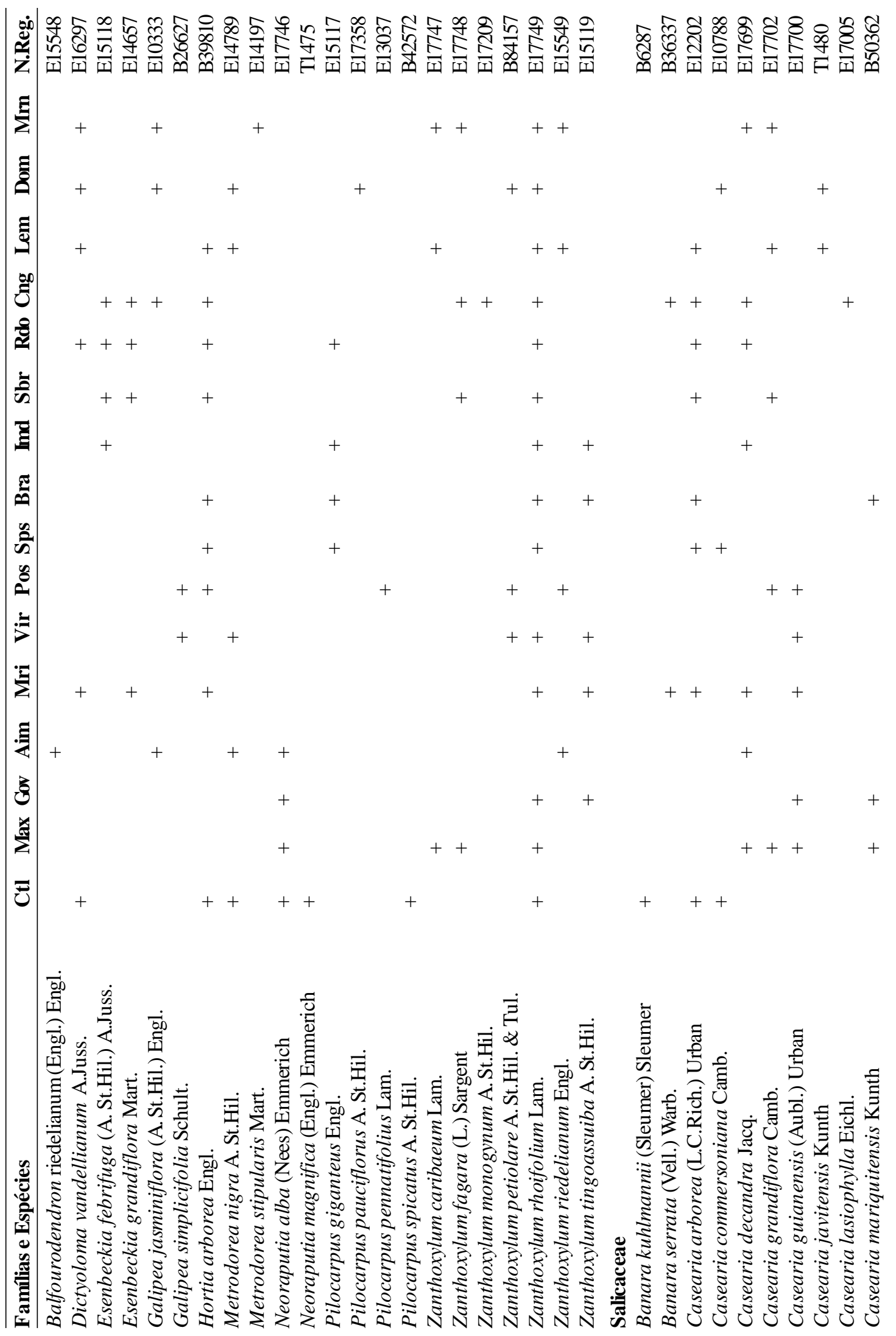

Rodriguésia 56 (87): 185-235. 2005 


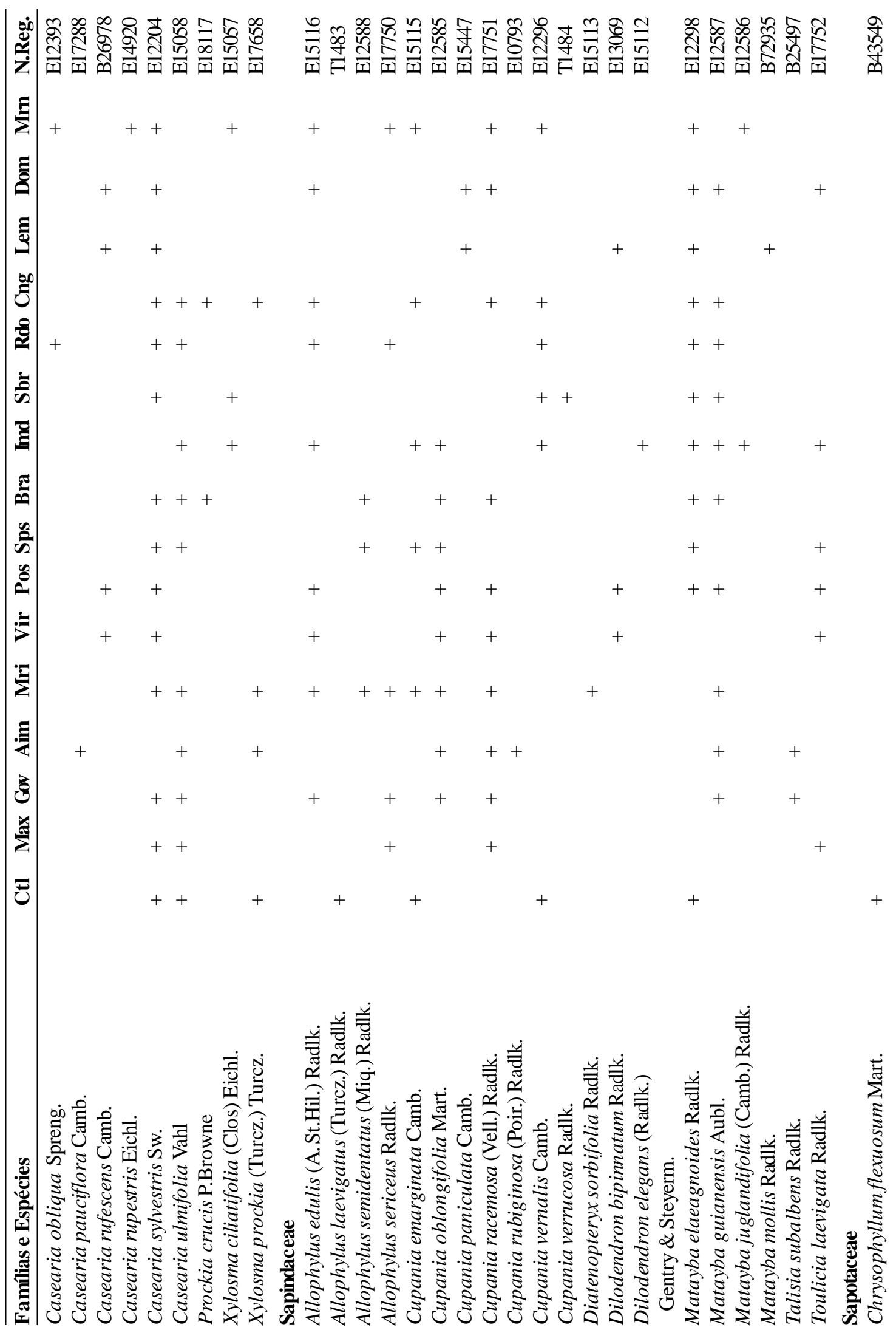




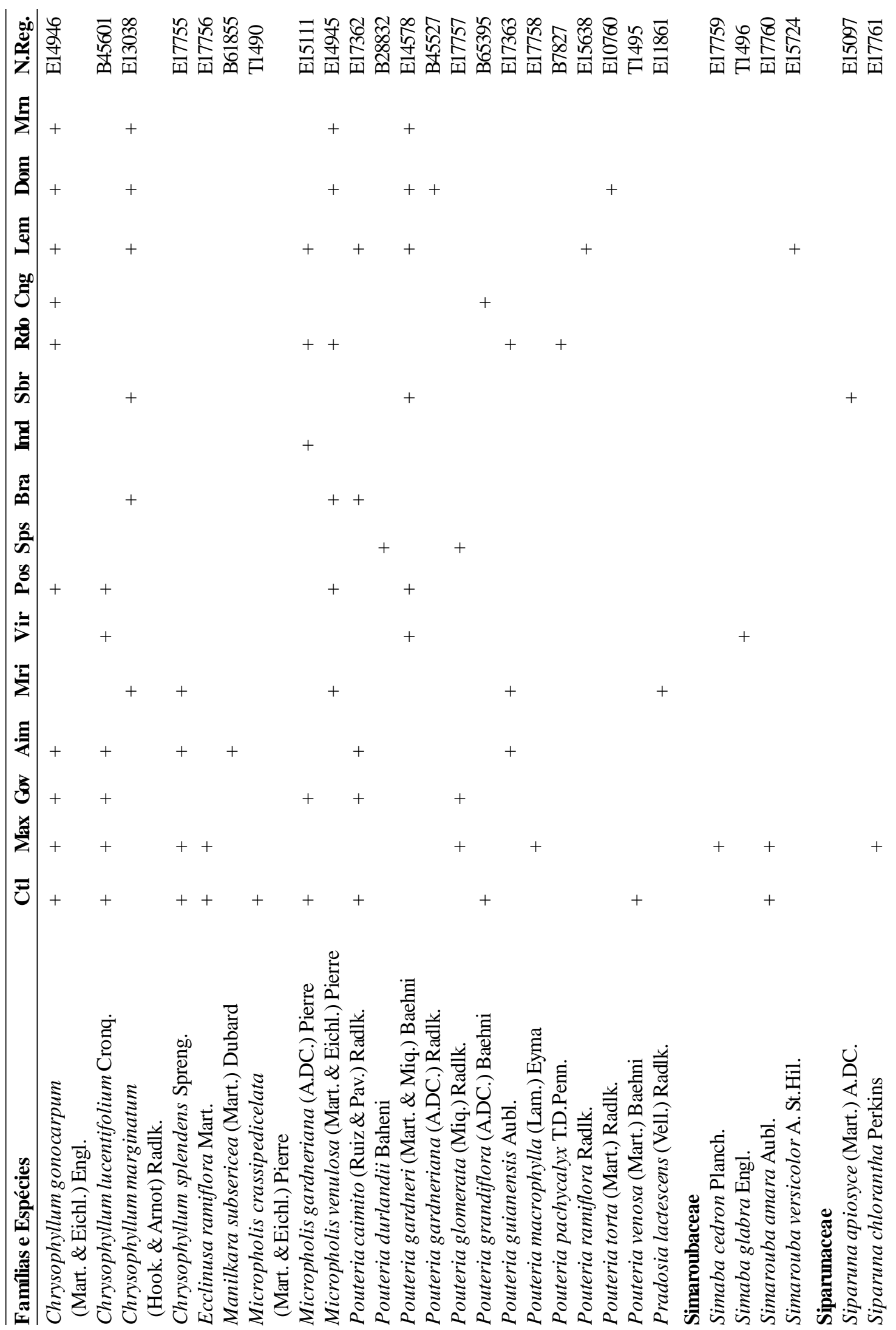

Rodriguésia 56 (87): 185-235. 2005 


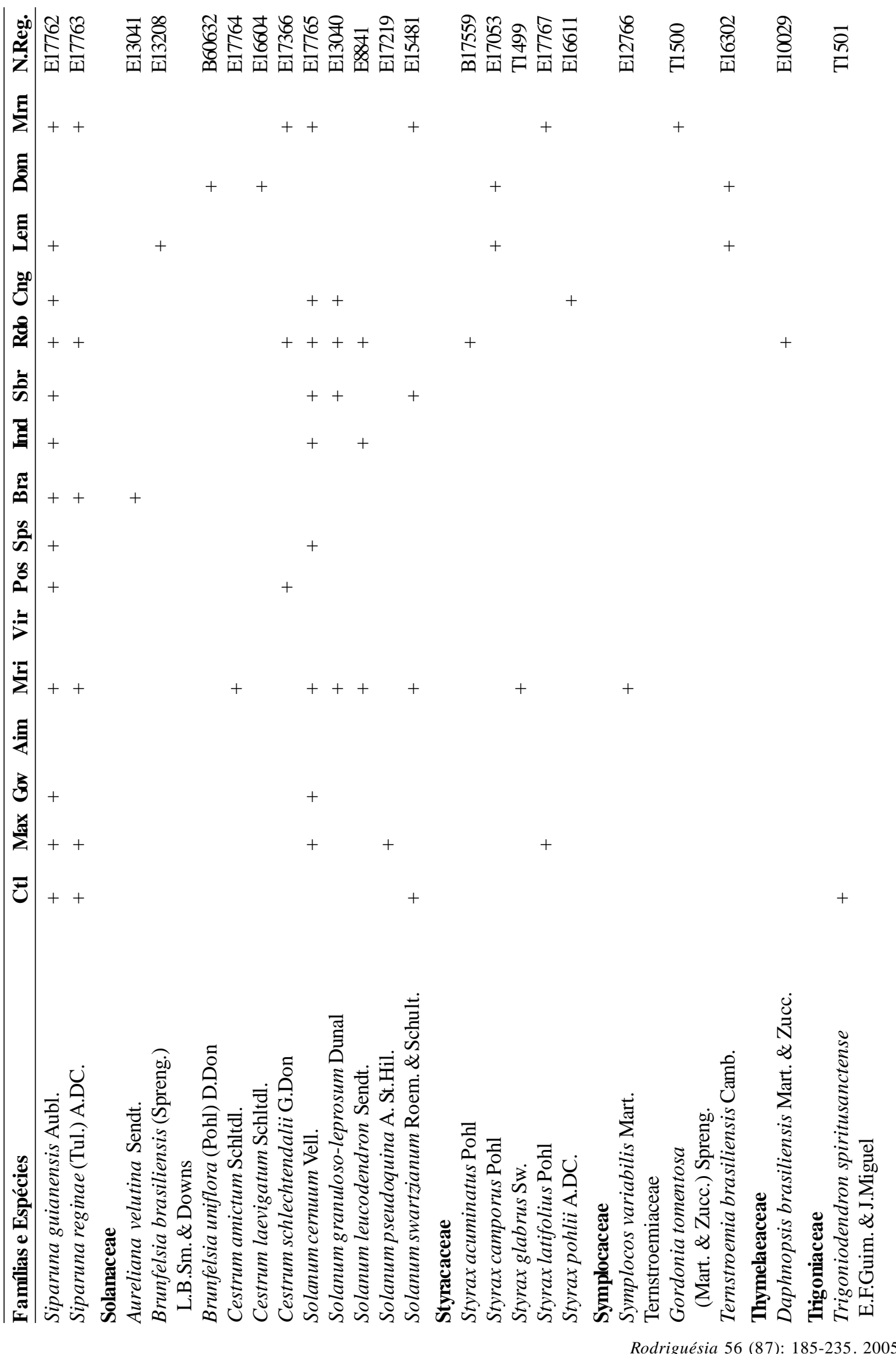




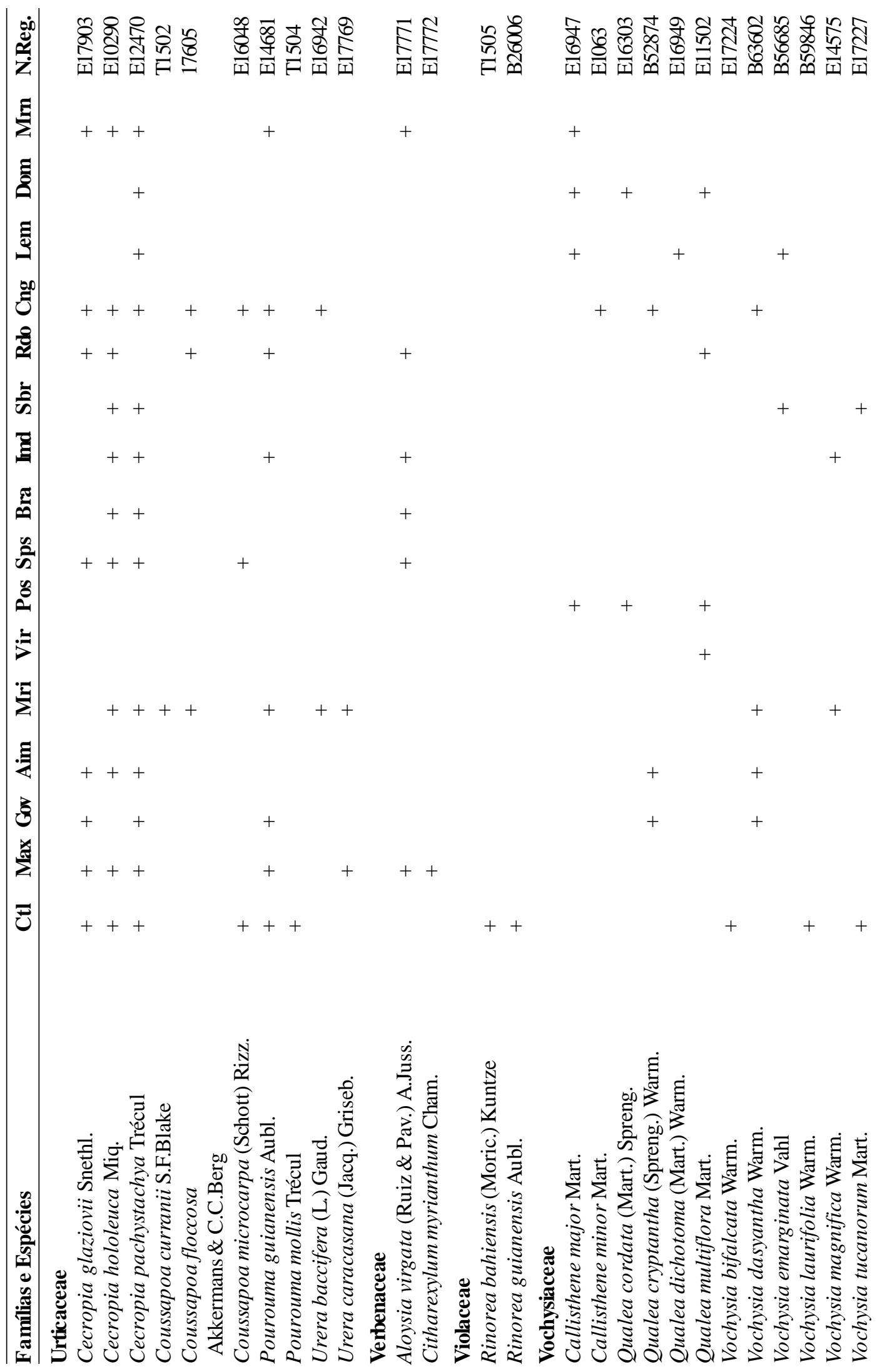

Rodriguésia 56 (87): 185-235. 2005 


\section{Agradecimentos}

Aos pesquisadores do Instituto de Pesquisas Jardim Botânico do Rio de Janeiro, Haroldo C. Lima e José Fernando A. Baumgratz, às pesquisadoras do Instituto de Botânica de São Paulo, Inês Cordeiro, Maria Lúcia Kawasaki e Lúcia Rossi, e aos pesquisadores da Universidade Federal de Minas Gerais, João Renato Stehmann e Marcos Sobral, pelo atencioso auxílio na identificação do material botânico. Aos pesquisadores Rafaela C. Forzza, do Instituto de Pesquisas Jardim Botânico do Rio de Janeiro, Daniel S. Pifano, da Universidade Federal de Juiz de Fora, e Alexandre F. da Silva, da Universidade Federal de Viçosa, e Mayke B. Costa, da Universidade Estadual do Espírito Santo, pela gentileza e confiança de nos fornecer seus dados, ainda inéditos, das áreas de Descoberto, Morro do Imperador, Ipatinga e Cachoeiro de Itapemirim, respectivamente. Agradecemos ainda a valiosa colaboração anônima de dois revisores que melhorou substancialmente o manuscrito.

\section{REFERÊNCIAS Bibliográficas}

Aguiar, A. P.; Chiarello, A. G.; Mendes, S. L. \& Matos, E. N. 2003. The Central and Serra do Mar Corridors in the Brazilian Atlantic Foret. In: Galindo-Leal, C. \& Câmara, I. G. (eds.). The Atlantic Forest of South América. Washington, Center for Applied Biodiversity Science, p. 118132.

Almeida, D. S. \& Souza, A. L. 1997. Florística e estrutura de um fragmento de floresta Atlântica no município de Juiz de Fora, Minas Gerais. Revista Árvore 21 (2): 221-230.

Amorim, H. B. 1984. Inventário das floresta nativas dos Estados do Rio de Janeiro e Espírito Santo. Brasília, Instituto Brasileiro de Desenvolvimento Florestal, $204 \mathrm{p}$.

APG. 2003. An update of the Angiosperm Phylogeny Group classification for the orders and families of flowering plants: APG II. Botanical Journal of the Linnean Society 141: 399-436.
Borém, R. A. T. \& Oliveira-Filho, A. T. 2002. Fitossociologia do estrato arbóreo em uma topossequiência alterada de mata atlântica, no município de Silva Jardim-RJ. Revista Árvore 26 (6): 727-742.

Borém, R. A. T. \& Ramos, D. P. 2001. Estrutura fitossociológica da comunidade arbórea de uma topossequiência pouco alterada de uma área de floresta atlântica, no município de Silva Jardim-RJ. Revista Árvore 25(1): 131-140.

Braz, D. M.; Moura, M. V. L. P. \& Rosa, M. M. T. 2004. Chave de identificação para as espécies de Dicotiledôneas arbóreas da Reserva Biológica de Tinguá, RJ, com base em caracteres vegetativos. Acta Botanica Brasilica 18 (2): 225-240.

CABS, 2000. Designing sustainable landscapes. Washington, Center for Applied Biodiversity Science, $29 \mathrm{p}$.

Campos, M. T. V. A. 1995. Composição florística e aspectos da estrutura e da dinâmica de três capões na Serra do Cipó, Minas Gerais, Brasil. Dissertação de Mestrado, São Paulo, Universidade de São Paulo, 87 p.

Carneiro, J. S. \& Valeriano, D. M. 2003. Padrão espacial da diversidade beta da Mata Atlântica - Uma análise da distribuição da biodiversidade em banco de dados geográficos. $11^{\circ}$ Sociedade Brasileira de Sensoriamento Remoto, Anais. Belo Horizonte, Instituto Nacional de Pesquisas Espaciais, p. 629-636.

Carvalho, D. A.; Oliveira-Filho, A. T.; Vilela, E. A. \& Curi, N. 2000. Florística e estrutura da vegetação arbórea de um fragmento de floresta semidecidual às margens do reservatório da Usina Hidrelétrica Dona Rita (Itambé do Mato Dentro, MG). Acta Botanica Brasilica 14 (1): 37-55.

CETEC. 1982. Levantamento da vegetação do Parque Estadual do Rio Doce. Belo Horizonte, Centro Tecnológico de Minas Gerais, 89 p. 
1989. Composição florística e tipos vegetacionais da Estação de Proteção e Desenvolvimento Ambiental de Peti, Relatório final. Belo Horizonte, Centro Tecnológico de Minas Gerais, 56 p.

Cosenza, B. A. P. 2003. Florística e fitossociologia na Reserva Particular do Patrimônio Natural - RPPN, "Dr. Marcos Vidigal de Vasconcelos", no município de Tombos, MG. Dissertação de Mestrado, Viçosa, Universidade Federal de Viçosa, 83 p.

Costa, M. B.; Natali, R. G.; Sansevero, J. B.; Pires, J. P. A.; Zaneti, L. Z.; Silva, G. F.; Bragança, H. B. \& Pezzopane, J. E. 2004. Estudo da estrutura fitossociológica de um fragmento florestal na Floresta Nacional de Pacotuba-ES. 55 ${ }^{\circ}$ Congresso Nacional de Botânica, Resumos. Viçosa, SBB, p. 97.

DNMET. 1992. Normais climatológicas (1961-1990). Brasília, Ministério da Agricultura, Departamento Nacional de Meteorologia, $130 \mathrm{p}$.

Elias Jr., E. 1998. Florística e estrutura fitossociológica de fragmentos de floresta atlântica do município de Eunápolis, Bahia. Dissertação de Mestrado, Viçosa, Universidade Federal de Viçosa, 88 p.

Ferraz, E. M. N.; Araújo, E. L. \& Silva, S. I. 2004. Floristic similarities between lowland and montane áreas of Atlantic Coastal Forest in Northeastern Brazil. Plant Ecology 174 (1): 59-70.

Ferreira, R. L. C. 1997. Estrutura e dinâmica de uma floresta secundária de transição, Rio Vermelho e Serra Azul de Minas, MG. Tese de Doutorado, Viçosa, Universidade Federal de Viçosa, 208 p.

FNMA \& Instituto ECOTEMA. 2001. Zoneamento ambiental da APA Petrópolis - 2a. Etapa e banco de dados georreferenciados. Petrópolis, Fundação Nacional do Meio Ambiente e Instituto de Ecologia e Tecnologia de Meio Ambiente, $689 \mathrm{p}$.

Galindo-Leal, C. \& Câmara, I. G. 2003. Atlantic Forest hotspot status: an overview.
In: Galindo-Leal, C. \& Câmara, I. G. (eds.). The Atlantic Forest of South América. Washington, Center for Applied Biodiversity Science, p. 3-11.

Guedes, R. R. 1989. Composição floristica e estrutura de um trecho de mata perturbada de baixada no municipio de Magé, Rio de Janeiro. Arquivos do Jardim Botânico do Rio de Janeiro 29: 155-200.

Guedes-Bruni, R. R. 1998. Composição, estrutura e similaridade florística de dossel em seis unidades fisionômicas de mata atlântica no Rio de Janeiro. Tese de Doutorado, São Paulo, Universidade de São Paulo, 347 p.

Harley, R. M. \& Mayo, S. J. 1980. Towards a checklist of the flora of Bahia. Kew, Royal Botanic Gardens, 137 p.

Heinsdijk, D.; Macêdo, J. G.; Andel, S. \& Ascoly, R. B. 1965. A floresta do norte do Espírito Santo - Dados e conclusões dum inventário florestal pilôto. Rio de Janeiro, Boletim do Departamento de Recursos Naturais Renováveis do Ministério da Agricultura ${ }^{\circ} 7$.

IBDF 1981. Plano de manejo da Reserva Biológica de Poço das Antas. Documento Técnico No. 10, Brasília, Instituto Brasileiro de Desenvolvimento Florestal, $110 \mathrm{p}$.

Jesus, R. M. \& Garcia, A. 1992. Index seminum - Reserva Florestal de Linhares, Espírito Santo - Brasil. II Congresso Nacional sobre Essências Nativas, Anais... Revista do Instituto Florestal de São Paulo 4(2): 306-317.

Kurtz, B. C. \& Araujo, D. S. D. 2000. Composição florística e estrutura do componente arbóreo de um trecho de Mata Atlântica na Estação Ecológica Estadual do Paraíso, Cachoeiras de Macacu, Rio de Janeiro, Brasil. Rodriguésia 51(78/115): 69-112.

Leoni, L. S. 1991. Reconstituição e preservação da vegetação arbórea do rio Carangola. Levantamento preliminar. Pabstia 2: 103145. 
Lima, M. P. M. \& Guedes-Bruni, R. R. 1994. Reserva Ecológica de Macaé de Cima Nova Friburgo - RJ: aspectos florísticos das espécies vasculares. Rio de Janeiro, Jardim Botânico do Rio de Janeiro, 361 p.

Lombardi, J. A. \& Gonçalves, M. 2000. Composição florística de dois remanescentes de Mata Atlântica do sudeste de Minas Gerais, Brasil. Revista Brasileira de Botânica 23(3): 255-282.

Lopes, W. P.; Silva, A. F.; Souza, A. L. \& Meira-Neto, J. A. 2002. Estrutura fitossociológica de um trecho de vegetação arbórea no Parque Estadual do Rio Doce - Minas Gerais, Brasil. Acta Botanica Brasilica 16(4): 443-456.

Marangon, L. C.; Soares, J. J. \& Feliciano, A. L. P. 2003. Florística arbórea da Mata da Pedreira, município de Viçosa, Minas Gerais. Revista Árvore 27(2): 207-215.

McCune, B. \& Mefford, M. J. 1999. PC-ORD version 4.0, multivariate analysis of ecological data, Users guide. Glaneden Beach, MjM Software Design, 148 p.

Meguro, M.; Pirani, J. R.; Mello-Silva, R. \& Giulietti, A. M. 1996a. Estabelecimento de matas ripárias e capões nos ecossistemas campestres da Cadeia do Espinhaço, Minas Gerais. Boletim de Botânica da Universidade de São Paulo 15: 1-11.

1996b. Caracterização florística e estrutural de matas ripárias e capões de altitude na Serra do Cipó, Minas Gerais. Boletim de Botânica da Universidade de São Paulo 15: 13-29.

Meira-Neto, J. A. \& Martins, F. R. 2000a. Estrutura da Mata da Silvicultura, uma Floresta Semidecidual Montana no município de Viçosa-MG. Revista Árvore 24(2): 151-160. . 2000b. Composição florística do estrato herbáceo-arbustivo de uma Floresta Estacional Semidecidual em Viçosa-MG. Revista Árvore 24(4): 407-416.

2002. Composição florística de uma Floresta Estacional Semidecidual
Montana no município de Viçosa - MG. Revista Árvore 26(4): 437-446.

Meira-Neto, J. A.; Rêgo, M. M.; Coelho, D. J. S. \& Ribeiro, F. G. 2003. Origem, sucessão e estrutura de uma floresta de galeria periodicamente alagada em Viçosa-MF. Revista Árvore 27(4): 561-574.

Meira-Neto, J. A.; Souza, A. L.; Silva A. F. \& Paula, A. 1997a. Estrutura de uma floresta estacional semidecidual aluvial em área diretamente afetada pela Usina Hidrelétrica de Pilar, Ponte Nova, Zona da Mata de Minas Gerais. Revista Árvore 21(2): 213-219.

1997b. Estrutura de uma floresta estacional semidecidual submontana em área diretamente afetada pela Usina Hidrelétrica de Pilar, Ponte Nova, Zona da Mata de Minas Gerais. Revista Árvore 21(3): 337-344.

1997c. Estrutura de uma floresta estacional semidecidual insular em área de influência da Usina Hidrelétrica de Pilar, Ponte Nova, Zona da Mata de Minas Gerais. Revista Árvore 21(4): 493-500.

1998. Estrutura de uma floresta estacional semidecidual insular em área diretamente afetada pela Usina Hidrelétrica de Pilar, Guaraciaba, Zona da Mata de Minas Gerais. Revista Árvore 22(2): 179-184.

MMA 2002. Biodiversidade brasileira Avaliação e identificação de áreas e ações prioritárias para conservação, utilização sustentável e repartição dos benefícios da biodiversidade nos biomas brasileiros. Brasília, Ministério do Meio Ambiente, Secretaria de Biodiversidade e Florestas, 404 p.

Moreno, M. R.; Nascimento, M. T. \& Kurtz, B. 2003. Estrutura e composição florística do estrato arbóreo em duas zonas altitudinais na mata atlântica de encosta da região do Imbé, RJ. Acta Botanica Brasilica 17(3): 325-486. 
Mori, S. A.; Boom, B. M.; Carvalho, A. M. \& Santos, T. S. 1983. Southern Bahian moist forests. Botanical Review 49(2): 155-232.

Myers, N.; Mittermeir, R. A.; Mittermeir, C. G.; Fonseca, G. A. B. \& Kent, J. 2000. Biodiversity hotspots for conservation priorities. Nature 403: 853-858.

Neves, G. M. S. 2001. Florística e estrutura da comunidade arbustivo-arbórea em dois remanescentes de Floresta Atlântica secundária - Reserva Biológica do Poço das Antas, Silva Jardim, RJ. Dissertação de Mestrado, Rio de Janeiro, Museu Nacional, Universidade Federal do Rio de Janeiro.

Oliveira-Filho, A. T. \& Fontes, M. A. L. 2000. Patterns of floristic differentiation among Atlantic forests in south-eastern Brazil, and the influence of climate. Biotropica 32(4b): 793-810.

Oliveira-Filho, A. T.; Vilela, E. A.; Gavilanes, M. L. \& Carvalho, D. A. 1994. Comparison of the woody flora and soils of six areas of montane semi-deciduous forest in southern Minas Gerais, Brazil. Edinburgh Journal of Botany 51(3): 355389.

Oliveira-Filho, A. T.; Carvalho, D. A.; Vilela, E. A.; Curi, N. \& Fontes, M. A. L. 2004. Diversity and structure of the tree community of a patch of tropical secondary forest of the Brazilian Atlantic Forest Domain 15 and 40 years after logging. Revista Brasileira de Botânica 27(4): 685-701.

Paraguassu, L. A. A. 1999. Levantamento florístico e fitossociológico da nascente do rio dos mangues, Porto Seguro, Bahia. Monografia de Bacharelado, Salvador, Universidade Federal da Bahia, 76 p.

Paula, A.; Lopes, W. P.; Silva, A. F. \& MeiraNeto, J. A. A. 2000. Levantamento florístico das espécies de porte arbóreo de cinco fragmentos florestais na Área de Proteção Ambiental Ipanema In: 51 ${ }^{\circ}$ Congresso Nacional de Botânica, Anais..., Brasília, SBB, p. 218.
Paula, A.; Silva, A. F.; de Marco Júnior, P.; Santos, F. A. M. \& Souza, A. L. 2004. Sucessão ecológica da vegetação arbórea em uma Floresta Estacional Semidecidual, Viçosa, MG, Brasil. Acta Botanica Brasilica 18(3): 401-699.

Pedralli, G. \& Teixeira, M. C. B. 1997. Levantamento florístico e principais fisionomias da Estação de Pesquisa e Desenvolvimento Ambiental de Peti, Santa Bárbara, estado de Minas Gerais, Brasil. Iheringia, Série Biológica 48: 15-40.

Pedralli, G.; Freitas, V. L. O.; Meyer, S. T.; Teixeira, M. C. B. \& Gonçalves, A. P. S. 1997. Levantamento florístico na Estação Ecológica do Tripuí, Ouro Preto, Minas Gerais. Acta Botanica Brasilica 11(2): 191-213.

Peixoto, A. L. \& Gentry, A. 1990. Diversidade e composição florística da mata de tabuleiro na Reserva Florestal de Linhares (Espírito Santo, Brasil). Revista Brasileira de Botânica 13(1): 19-25.

Peixoto, G. L.; Martins, S. V.; Silva, A. F. \& Silva, E. 2004. Composição florística do componente arbóreo de um trecho de Floresta Atlântica na Área de Proteção Ambiental da Serra da Capoeira Grande, Rio de Janeiro, RJ, Brasil. Acta Botanica Brasilica 18(1): 151-160.

Pifano, D. S. 2004. Checklist da flora do morro do Imperador - Juiz de Fora - MG. Monografia de Bacharelado, Juiz de Fora, Universidade Federal de Juiz de Fora, 37 p.

Pirani, J. R.; Giulietti, A. M.; Mello-Silva, R. \& Meguro, M. 1994. Checklist and patterns of geographic distribution of the vegetation of Serra do Ambrósio, Minas Gerais, Brazil. Revista Brasileira de Botânica 17(2): 133-147.

Rede Nacional de Agrometeorologia. 2004. Normais climatológicas e balanços hídricos (http://masrv54.agricultura.gov.br/rna).

Ribas, R. F.; Meira-Neto, J. A.; Silva, A. F. \& Souza, A. L. 2003. Composição florística de dois trechos em diferentes etapas serais de uma floresta estacional semidecidual 
em Viçosa, Minas Gerais. Revista Árvore 27(6): 821-830.

Ribeiro, C. A. N. 2003. Florística e fitossociologia de um trecho de floresta atlântica de altitude da Fazenda da Neblina, Parque Estadual da Serra do Brigadeiro, Minas Gerais. Dissertação de Mestrado, Viçosa, Universidade Federal de Viçosa, 75 p.

Rodrigues, H. C. 1996. Composição florística e estrutura fitossociológica de um trecho de mata atlântica na Reserva Biológica do Tinguá, Nova Iguaçu, RJ. Dissertação de Mestrado, Rio de Janeiro, Universidade Federal do Rio de Janeiro, 94 p.

Rodrigues, P. J. F. 2004. A vegetação da Reserva Biológica União e os efeitos de borda na mata atlântica fragmentada. Tese de Doutorado, Campos dos Goytacazes, Universidade Estadual do Norte Fluminense, $153 \mathrm{p}$.

Salis, S. M.; Shepherd, G. J. \& Joly, C. A. 1995. Floristic comparison of mesophytic semi-deciduous forests of the interior of the state of São Paulo, southeast Brazil. Vegetatio 119(2): 155-164.

Salomão, A. L. F. 1998. Subsídios técnicos para a elaboração do Plano de Manejo da Floresta Nacional do Rio Preto - ES. Tese de Doutorado, Viçosa, Universidade Federal de Viçosa, 132 p.

Santos, N. 1976. Plantas existentes no Parque Nacional da Tijuca. Brasil Florestal 26(1): 54-68.

Scarano, F. R. 2002. Structure, function and floristic relationships of plant communities in stressful habitats marginal to the Brazilian Atlantic Rainforest. Annals of Botany 90: 517-524.

Scudeller, V. V. \& Martins F. R. 2003. Fitogeo -Um banco de dados aplicado à fitogeografia. Acta Amazonica 33(1): 9-21.

Scudeller, V. V.; Martins, F. R. \& Shepherd G. J. 2001. Distribution and abundance of arboreal species in the atlantic ombrophilous dense forest in Southeastern Brazil. Plant Ecology 152(2): 185-199.
Sevilha, A. C.; Paula, A; Lopes, W. P. \& Silva, A. F. 2001. Fitosociologia de estrato arbóreo de um trecho de Floresta Estacional no Jardim Botânico da Universidade Federal de Viçosa (face sudoeste), Viçosa, Minas Gerais. Revista Árvore 25(4): 431-443.

Silva, A. F.; Fontes, N. R. L. \& Leitão-Filho, H. F. 2000. Composição florística e estrutura horizontal de estrato arbóreo de um trecho da Mata da Biologia da Universidade Federal de Viçosa - Zona da Mata de Minas Gerais. Revista Árvore 24(1): 397-405.

Silva, G. C. \& Nascimento, M. T. 2001. Fitossociologia de um remanescente de mata sobre tabuleiros no norte do estado do Rio de Janeiro (Mata do Carvão). Revista Brasileira de Botânica 214(1): 51-62.

Silva, J. M. C. \& Casteleti, C. H. M. 2003. Status of the biodiversity of the Atlantic Forest of Brazil. : Galindo-Leal, C. \& Câmara, I. G. (eds.). The Atlantic Forest of South América. Washington, Center for Applied Biodiversity Science, p. 43-59.

Silva, S. F.; Oliveira, R. V.; Santos, N. R. L. \& Paula, A. 2003. Composição florística e grupos ecolológicos das espécies de um trecho de floresta semidecídua submontana da Fazenda São Geraldo, Viçosa-MG. Revista Árvore 27(3): 311-319.

Siqueira, M. F. 1994. Análise florística e ordenação de espécies arbóreas da Mata Atlântica através de dados binários. Dissertação de Mestrado, Campinas, Universidade Estadual de Campinas, $143 \mathrm{p}$.

Soares, R. O. \& Ascoly, R. B. 1970. Florestas costeiras do litoral leste (Inventário florestal de reconhecimento). Brasil Florestal 1(1): 9-21.

Soares-Filho, A. O. 2000. Estudo fitossociológico de duas florestas em região ecotonal no planalto de Vitória da Conquista, Bahia, Brasil. Dissertação de Mestrado, São Paulo. Universidade de São Paulo, 147 p.

Souza, A. L. 1998. Avaliação florística, fitossociológica e paramétrica de um fragmento 
defloresta atlântica secundária, município de Pedro Canário, Espírito Santo. Documento SIF - 018. Viçosa, Sociedade de Investigações Florestais, SIF, 112 p.

Souza, A. L.; Meira-Neto, J. A. A. \& Schettino, S. 1998. Avaliação florística, fitossociológica e paramétrica de um fragmento de floresta atlântica secundária, município de Caravelas, Bahia. Documento SIF - 019. Viçosa, Sociedade de Investigações Florestais, SIF $97 \mathrm{p}$.

Tavares, S.; Paiva, F. A. F; Carvalho, G. H. \& Tavares, E. J. S. 1979. Inventário florestal no Estado da Bahia, I - Resultados de um inventário florestal nos municípios de Una, Porto Seguro, Santa Cruz de Cabrália, Prado, Itamaraju, Belmonte e Ilhéus. Recursos Vegetais $\mathrm{n}^{\circ}$. 9, Recife, Superintendência do Desenvolvimento do Nordeste, Departamento de Recursos Naturais. 234 p.

ter Braak, C. J. F. 1987. The analysis of vegetation-environment relationship by canonical correspondence analysis. Vegetatio 69 (1): 69-77.

1988. Canoco - a Fortran program for canonical community ordinatin by (Partial) (Detrended) (Canonical) correspondence analysis and redundancy analysis, version 2. 1. Wageningen, TNO, (Technical report LWA-88-2).

1995. Ordination. In: Jongman, R. H.

G.; ter Braak, C. J. F. \& van Tongeren,

O. F. R. (eds.). Data analysis in community and landscape ecology. Cambrigde, Cambridge University Press, p. 91-173.

Thomas, W. W. \& Carvalho, A. M. 2004a. Preliminary checklist of the plants of the Mata da Esperança. New York, New York Botanical Garden (www.nybg.org/ bsci/res/ME.html).

2004b. Preliminary checklist of the plants of Monte Pascoal National Park. New York, New York Botanical Garden (www.nybg.org/bsci/res/MP.html).
Thomas, W. W.; Carvalho, A. M.; Amorim, A. \& Garrison, J. 2004. Preliminary checklist of the flora of the Una Biological Reserve. New York, New York Botanical Garden (www.nybg.org/bsci/res/una.html).

Thomaz, L. \& Monteiro, R. 1997. Composição florística da mata atlântica de encosta da Estação Biológica de Santa Lúcia, município de Santa Teresa-ES. Boletim do Museu de Biologia Mello Leitão 7: 348.

Thorntwaite, C. W. 1948. An approach toward a rational classification of climate. Geographical Review 38(1): 55-94.

Torres, R. B.; Martins, F. R. \& Gouvêa, L. S. K. 1997. Climate, soil and tree flora relationships in forests in the state of São Paulo, southeastern Brazil. Revista Brasileira de Botânica 20(1): 41-49.

Veloso, H. P. 1945. As comunidades e estações botânicas de Teresópolis, Estado do Rio de Janeiro (com um ensaio de chave dendrológica). Boletim do Museu Nacional 3: 1-95.

1946a. A vegetação do município de Ilhéus, Estado da Bahia, I - Estudo sinecológico das áreas de pesquisas sobre a febre amarela silvestre realizado pelo SEPFA. Memórias do Instituto Oswaldo Cruz 44: 13-103.

1946b. A vegetação do município de Ilhéus, Estado da Bahia, II - Observação e ligeiras considerações acêrca de espécies que ocorrem na região - Chave analítica das espécies arbóreas. Memórias do Instituto Oswaldo Cruz 44: 221-293.

Walter, H. 1985. Vegetation of the earth and ecological systems of the geo-biosphere. 3rd. ed., Berlim, Springer-Verlag.

Werneck, M. S.; Pedralli, G.; Koenig, R. \& Giseke, L. F. 2000. Florística e estrutura de três trecho de uma floresta semidecídua na Estação Ecológica do Tripuí, Ouro Preto, MG. Revista Brasileira de Botânica 23(1): 97-106. 

